Review

\title{
A Review on the Thermal Characterisation of Natural and Hybrid Fiber Composites
}

\author{
Jorge S. S. Neto (D), Henrique F. M. de Queiroz, Ricardo A. A. Aguiar and Mariana D. Banea *(D) \\ Federal Centre of Technological Education in Rio de Janeiro (CEFET/RJ), Rio de Janeiro 20271-110, Brazil; \\ jorge.neto@aluno.cefet-rj.br (J.S.S.N.); henrique.queiroz@aluno.cefet-rj.br (H.F.M.d.Q.); \\ ricardo.aguiar@cefet-ri.br (R.A.A.A.) \\ * Correspondence: mdbanea@gmail.com
}

Citation: Neto, J.S.S.; de Queiroz, H.F.M.; Aguiar, R.A.A.; Banea, M.D. A Review on the Thermal Characterisation of Natural and Hybrid Fiber Composites. Polymers 2021, 13, 4425. https://doi.org/ $10.3390 /$ polym 13244425

Academic Editor: Dan Rosu

Received: 14 November 2021

Accepted: 8 December 2021

Published: 16 December 2021

Publisher's Note: MDPI stays neutral with regard to jurisdictional claims in published maps and institutional affiliations.

Copyright: (c) 2021 by the authors. Licensee MDPI, Basel, Switzerland. This article is an open access article distributed under the terms and conditions of the Creative Commons Attribution (CC BY) license (https:// creativecommons.org/licenses/by/ $4.0 /)$.
Abstract: The thermal stability of natural fiber composites is a relevant aspect to be considered since the processing temperature plays a critical role in the manufacturing process of composites. At higher temperatures, the natural fiber components (cellulose, hemicellulose, and lignin) start to degrade and their major properties (mechanical and thermal) change. Different methods are used in the literature to determine the thermal properties of natural fiber composites as well as to help to understand and determine their suitability for a certain applications (e.g., Thermogravimetric analysis (TGA), differential scanning calorimetry (DSC), and differential mechanical thermal analysis (DMA)). Weight loss percentage, the degradation temperature, glass transition temperature $\left(T_{g}\right)$, and viscoelastic properties (storage modulus, loss modulus, and the damping factor) are the most common thermal properties determined by these methods. This paper provides an overview of the recent advances made regarding the thermal properties of natural and hybrid fiber composites in thermoset and thermoplastic polymeric matrices. First, the main factors that affect the thermal properties of natural and hybrid fiber composites (fiber and matrix type, the presence of fillers, fiber content and orientation, the treatment of the fibers, and manufacturing process) are briefly presented. Further, the methods used to determine the thermal properties of natural and hybrid composites are discussed. It is concluded that thermal analysis can provide useful information for the development of new materials and the optimization of the selection process of these materials for new applications. It is crucial to ensure that the natural fibers used in the composites can withstand the heat required during the fabrication process and retain their characteristics in service.

Keywords: natural fiber reinforced composite material; thermal analysis; thermogravimetric analysis (TGA); differential scanning calorimetry (DSC); differential mechanical thermal analysis (DMA)

\section{Introduction}

The application of composites has continuously increased across many industries, in particular in the automotive and aerospace industries where lower weight and high resistance are key factors. The most commonly used fibers that attend these requirements are carbon and glass fibers [1-3]. However, nowadays, the industry is seeking new desirable characteristics of composite materials, such as renewability, eco-friendliness, and low cost. Consequently, there has been great interest in research and innovation in natural fiber composites owing to the advantages of these materials compared to their synthetic fiber counterparts (i.e., lower environmental impact and lower cost), supporting their potential across a wide range of applications in several industrial sectors [4-9]. The natural fiberreinforced composites (NFRCs) are used mainly in non-structural car body parts, such as door panels, package trays, hat racks, instrument panels, internal engine covers, sun visors, boot liners, oil air filters, and even progressing to more structurally demanding parts, such as seat backs and exterior underfloor paneling [10,11]. Nowadays, most of the automotive makers, such as Audi, Volkswagen, Toyota, Daimler-Benz, Volvo, Ford, etc., 
use NFRCs to produce components. The continually growing demands for lightweight and fuel-efficient vehicles will further push the growth of NFRCs in the automotive market. There are other exciting market trends going forward in many different industries. For example, tri-dimensional hybrid natural fiber reinforcement preforms have been used recently by sports car manufacturers, such as Porsche and even McLaren in Formula 1 [12]. Other applications of NFRCs include sport equipment, musical instruments, aerospace, construction industry [12-14], and ballistic armour [15,16].

Several types of natural fibers are currently used in industry, such as jute, sisal, oil palm, kenaf, and flax, which are well established in the global market with a well-defined production line. However, new promising natural fibers are being discovered and used on a smaller scale or are still being used only for research. This is the case of the buriti and curaua fibers, for example, that still need some improvements in their production line to be more commercially affordable and reach widespread use $[17,18]$. They are used as reinforcement fibers in thermoset or thermoplastic polymeric matrix in a variety of applications [19]. Depending upon the matrix type, NFRCs are categorized into completely biodegradable or partially biodegradable composites.

The growing importance of natural fiber reinforced composites is reflected by the increasing number of publications (e.g., reviews, patents, book chapters, and books) during the recent years $[4,5,20-25]$. Therefore, it is important to study their thermal and mechanical behaviour in order to utilize their full potential. The thermal stability of natural fiber composites is a relevant aspect to be considered as the processing temperature plays a crucial role in the fabrication process of the composites. At higher temperatures, the natural fiber components (i.e., cellulose, hemicellulose, and lignin), start to degrade and the major properties (mechanical and thermal) of the composite change. Intense research efforts are continuously made and some of the shortcomings of NFRCs were addressed by recent advancements in fiber treatment and modification, exploration of new natural fibers, and hybridization. The fiber modification techniques provide improved fibermatrix interfacial adhesion, improved fiber roughness, and wettability and depend on the particular fiber/matrix used and the composite application, while the hybridization methods provide flexibility in fiber selection for the material properties according to the end-use application requirements.

Even though there are many recent review articles concerning the use of natural fibers in the production of natural hybrid composites [10,23,26-34], one topic that was not covered in any significant detail relates to the thermal characterisation of NFRCs. This paper provides an overview of the recent advances in the thermal properties of natural and hybrid natural fiber composites in thermoset and thermoplastic polymeric matrices. First, the main factors that affect the thermal properties of natural and hybrid fiber composite materials (fiber and matrix type, the presence of additive fillers, fiber content and orientation, the treatment of the fibers, manufacturing process, and type of loading) are briefly presented. Further, the methods used to determine the thermal properties of natural and hybrid composites are discussed. Finally, some conclusions and critical challenges and future perspectives and research activities are summarized.

\section{Factors That Affect the Thermal Properties of Natural and Hybrid Composites}

The main factors that affect the thermal properties of natural and hybrid fiber composite materials are: fiber and matrix type, the presence of additive fillers, fiber content and orientation, the treatment of the fibers, manufacturing process, and type of loading. In this section, these factors are briefly discussed.

\subsection{Type of Fiber}

The natural fibers are promising renewable alternatives to the traditional human-made fibers (i.e., glass and carbon fibers) in composite materials. Their consumption is increasing in different industrial sectors, such as aeronautical, automotive, civil, and naval, with an average annual growth of $7.5 \%$ and an expected global market demand around 35 million 
tons by 2022 [10]. The natural fibers can be divided into three main groups regarding their origin: mineral, animal, and cellulose/lignocellulose (see Figure 1). Mineral-based fibers were widely used in composite materials. However, their use presented many human health issues (carcinogenic parts that can be inhaled or ingested), nowadays being forbidden in many countries worldwide. The animal fibers present lower mechanical properties compared to the cellulose fibers, except for the silk fiber that presents high tensile strength [10]. However, the silk fibers are quite expensive and are more used in the textile industries [10]. The cellulose/lignocellulose fibers are the most used natural fibers due to their relatively low price and higher mechanical properties compared to other natural fibers and are the focus in the present review. They can also be subdivided into different categories corresponding to the plant part that originated them, as can be seen in Figure 1. Depending on the length, orientation, and type of natural fiber, randomly oriented (short), unidirectional, and woven fabrics are usually used as reinforcements in thermoset and thermoplastic matrices [35].

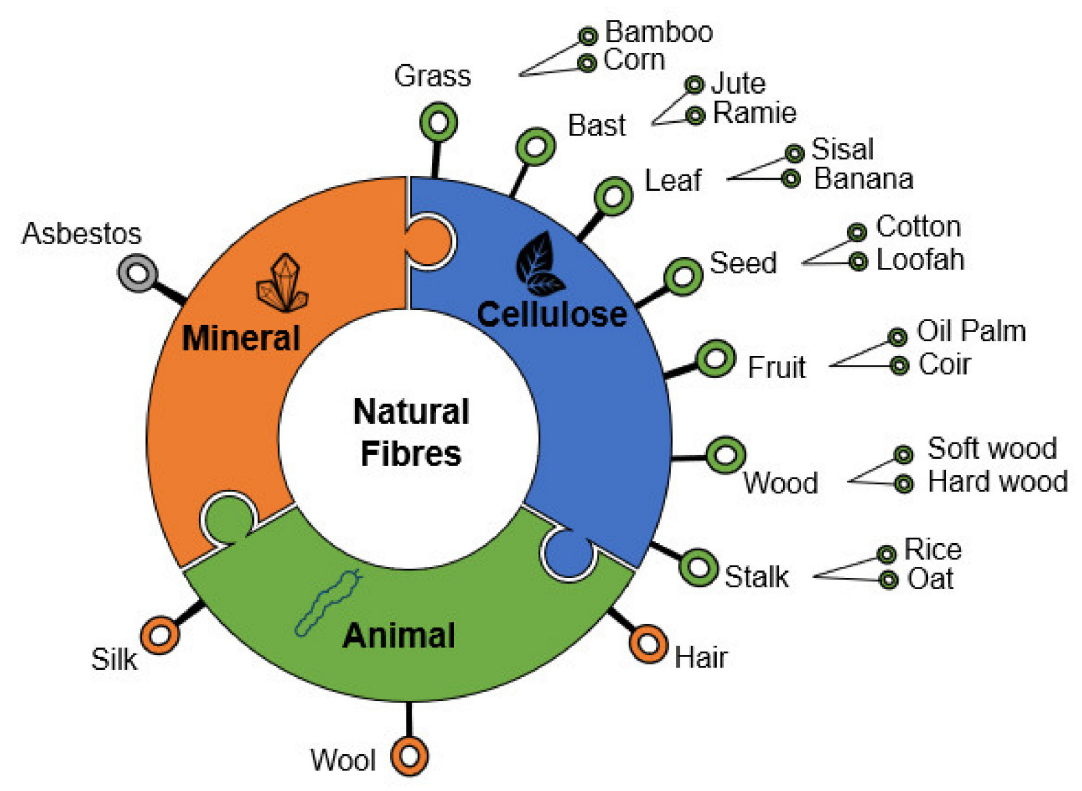

Figure 1. Schematic of natural fibers classification.

The thermal stability of any natural fiber is the maximum temperature at which a fiber decomposes [36]. It is known that various constituents of the natural fiber (i.e., hemicellulose, cellulose and lignin) decompose at different temperatures which leads to the complete decomposition of the fiber as a whole [37]. It was reported that, lignin starts degrading at a temperature around $200{ }^{\circ} \mathrm{C}$, while hemicelluloses and cellulosic constituents degraded at higher temperatures [38]. Usually, the thermal degradation of lignin and cellulose occurs in the temperature range of $300-450{ }^{\circ} \mathrm{C}$ [39]. The thermal stability of the natural fiber can be enhanced by removing a certain proportion of hemicelluloses and lignin constituents. However, fibers with lower lignin content are susceptible to thermal damage and often tend to damage secondary cell walls [40]. Other volatile or partially stable constituents (i.e., pectin, waxes, and water-soluble substances), may also be found in cellulose fibers. Thus, the thermal properties of the natural fiber leads to critical issues for the processing of natural fiber-reinforced thermoplastic composite products. For instance, the automotive interior part made of natural fiber reinforced composites can be affected by the high temperature inside the vehicle during the hot season. In addition, the thermal stability of these composites is a critical issue because of the poor heat resistance during a fire. If the natural fibers are exposed to temperatures higher than $250{ }^{\circ} \mathrm{C}$, they have a very high probability of burning, thus compromising the structural integrity of the component [41]. 
To summarize, the thermal stability of natural fiber composites is a relevant aspect to be considered as the processing temperature plays a crucial role in the fabrication process of the composites. Intense research efforts are continuously made and some of the shortcomings of NFRCs were addressed by recent advancements in fiber treatment and modification, by the exploration of new natural fibers and hybridization.

\subsection{Surface Treatment of Natural Fibers}

The surface treatment of natural fibers is usually performed to enhance their mechanical and thermal properties, before using them to manufacture a composite material. Fiber surface modification can improve the fiber-matrix interfacial bonding, roughness, and wettability and decrease the moisture absorption of the fibers $[5,42,43]$. As a result, better mechanical and thermal properties of the resulting composites can be achieved. The main surface modification methods used for natural fibers are: physical and chemical treatments.

The main physical treatments used to modify the surface of natural fibers are as follows: plasma, corona, ultraviolet (UV), heat treatments, electron radiation, and fiber beating. These treatments improve the adhesion between the fiber and matrix by changing the surface properties of the fibers without changing their structural composition [44,45].

The chemical treatments are a common way of increasing the interface adhesion between the fiber-matrix by chemical bonding or mechanical interlocking at the interface and decreases the water absorption of the fibers. This is achieved by using compounds that promote adhesion by chemically coupling the fibers to the matrix, such as: sodium hydroxide [46], silane [47], acetic acid [48], Benzoyl Chloride [49], maleated coupling agents [44], isocyanates [5], peroxide [50], and stearic acid [51].

Numerous researchers have investigated the effect of the fiber treatments on the thermal properties of NFRCs [36,52-74]. In general, fiber pre-treatments increased the thermal stability of the resulting NFRCs, mainly due to the removal of the waxy layers and other impurities from the fiber surface, as well as increasing the crystallinity [75-77]. However, some researchers found that surface treatments of natural fibers led to a decrease in degradation temperatures, signifying weakened thermal stability of the composites $[78,79]$. In addition, in some cases, the gain in thermal stability negatively affected the mechanical properties of composites. It was stated that the balance in improvements in thermal properties depends on fiber treatment type and time. It was also shown that the combination of treatments (mixed treatments) promoted increased thermal stability [80]. Table 1 summarizes the results from several recent studies on the effect of fiber treatments on the thermal properties of natural fiber composites.

Table 1. Effect of treatments on the thermal properties of natural fiber-reinforced composites.

\begin{tabular}{|c|c|c|c|c|}
\hline Fiber & Matrix & Treatment & Thermal Properties & Ref. \\
\hline Flax & Epoxy & $\begin{array}{c}5 \% \text { and } 10 \% \text { of } \\
\text { sodium bicarbonate }\end{array}$ & $\begin{array}{l}\text { By increasing the concentration of sodium } \\
\text { bicarbonate, negligible changes in the } T_{\mathrm{g}} \text { and } \\
\text { reductions in the } \tan \delta \text { peak heights were found. }\end{array}$ & [81] \\
\hline $\begin{array}{l}\text { Mulberry } \\
\text { (MF) }\end{array}$ & Polyester & $\begin{array}{c}\text { Alkalization (5\% ATMFC, } \\
10 \% \text { ATMFC and 15\% ATMFC) }\end{array}$ & $\begin{array}{l}10 \% \text { ATMFC samples presented higher } \\
\text { values of storage modulus and loss modulus } \\
\text { compared to the other cases studied. }\end{array}$ & [82] \\
\hline Jute & Polyester & $\begin{array}{l}5 \% \text { of alkali treatment, } \\
\text { poly (lactic acid)-coated } \\
\text { and mixed treatment }\end{array}$ & $\begin{array}{l}\text { The mixed and alkaline } \\
\text { treatment improved the } T_{g} \text {. }\end{array}$ & [83] \\
\hline $\begin{array}{l}\text { Buriti and } \\
\text { ramie }\end{array}$ & Polyester & $\mathrm{NaOH}(2.5$ and $10 \%)$ & $\begin{array}{l}\text { The buriti fiber starts to degrade at } 217^{\circ} \mathrm{C} \text {, } \\
\text { while the ramie fiber at } 247^{\circ} \mathrm{C} \text {. The alkalization } \\
\text { treatment of these fibers negatively affected } \\
\text { their properties when compared to the in } \\
\text { natura and washed cases. }\end{array}$ & [84] \\
\hline
\end{tabular}


Table 1. Cont.

\begin{tabular}{|c|c|c|c|c|}
\hline Fiber & Matrix & Treatment & Thermal Properties & Ref. \\
\hline Bamboo & $\begin{array}{l}\text { Epoxy, polyester, } \\
\text { and Vinyl ester }\end{array}$ & $\begin{array}{l}\text { Chemical }(10 \% \mathrm{NaOH}) \text { and } \\
\text { physical (milling method) }\end{array}$ & $\begin{array}{l}\text { The alkaline treatment enhanced } \\
\text { the thermal stability of the composites. }\end{array}$ & [85] \\
\hline Curauá & Polyester & $\begin{array}{c}10 \% \text { of barium hydroxide } \\
\mathrm{Ba}(\mathrm{OH})_{2} \text { for } 48 \mathrm{~h} \text { at } 25^{\circ} \mathrm{C} \text {, } \\
14 \% \text { of calcium hydroxide } \\
\mathrm{Ca}(\mathrm{OH})_{2} \text { for } 4 \mathrm{~h} \text { at } 70{ }^{\circ} \mathrm{C}, \\
10 \% \text { of potassium hydroxide } \\
(\mathrm{KOH}) \text { for } 1 \mathrm{~h} \text { at } 25^{\circ} \mathrm{C}, 5 \% \text { of } \\
\text { sodium hydroxide }(\mathrm{NaOH}) \\
\text { for } 2 \mathrm{~h} \text { at } 70{ }^{\circ} \mathrm{C} \text { and } 5 \% \text { of } \\
\text { silane (Trimethoxy (propyl) } \\
\text { for } 4 \mathrm{~h} \text { at } 25^{\circ} \mathrm{C}\end{array}$ & $\begin{array}{l}\text { The chemical treatment increased the } T_{\mathrm{g}} \text { of } \\
\text { the treated composite. The } \mathrm{Ca}(\mathrm{OH})_{2} \text { treatment } \\
\text { provided a } T_{\mathrm{g}} \text { of } 141.2^{\circ} \mathrm{C} \text {, compared to the } \\
133.69^{\circ} \mathrm{C} \text { of the untreated composite. }\end{array}$ & [86] \\
\hline Kenaf & PLA & Acetylation $(0.5,1,2$ and $3 \mathrm{~h})$ & $\begin{array}{l}\text { The thermal stability was improved } \\
\text { as treatment time was increased. }\end{array}$ & [87] \\
\hline Banana & $\mathrm{PP}$ & $\begin{array}{l}\text { Untreated, alkaline and } \\
\text { acetylated treatment }\end{array}$ & $\begin{array}{l}\text { The acetylation treatment improved } \\
\text { the thermal stability and raised up } \\
\text { the crystallization temperature. }\end{array}$ & [88] \\
\hline Jute & PLA & $\begin{array}{l}6 \% \text { benzoyl peroxide acetone } \\
\text { solution for about } 30 \mathrm{~min} \\
\text { after alkali pre-treatment }\end{array}$ & $\begin{array}{l}\text { Higher storage modulus and lower } \tan \delta \\
\text { compared to untreated composite. }\end{array}$ & [89] \\
\hline Kenaf & PU & $\begin{array}{l}\text { Acetylation, blocked } \\
\text { isocyanate, maleic anhydride } \\
\text { and permanganate treatment }\end{array}$ & $\begin{array}{l}\text { The acetylated treatment provided better } \\
\text { values for storage modulus }\left(\mathrm{E}^{\prime}\right) \text { when } \\
\text { compared to all other treatments. }\end{array}$ & [90] \\
\hline Banana + sisal & PLA & $\begin{array}{l}\text { Untreated and benzoyl } \\
\text { peroxide treatment }\end{array}$ & $\begin{array}{l}\text { The peroxide treatment improved the thermal } \\
\text { stability by delaying the thermal degradation. } \\
\text { No significant changes in the } T_{g} \\
\text { and melting temperature }\left(T_{m}\right) \text {. }\end{array}$ & [91] \\
\hline Jute + curauá & Epoxy & $\begin{array}{l}\text { Untreated, alkali, silane } \\
\text { and mixed treatment }\end{array}$ & $\begin{array}{l}\text { The chemical treatment improved } \\
\text { both } T_{g} \text { and thermal stability of the } \\
\text { composites. } \tan \delta \text { value decreased. }\end{array}$ & [65] \\
\hline Bamboo & $\begin{array}{l}\text { Epoxy, polyester } \\
\text { and vinyl ester }\end{array}$ & $\begin{array}{c}\text { Alkali (0 h- } 0 \%, 24 \text { h-10\%, } \\
48 \text { h-5, 10, 15\% and } 72 \text { h-10\%) }\end{array}$ & $\begin{array}{l}\text { The bamboo-epoxy composite treated } \\
\text { with the } 10 \% \text { of } \mathrm{NaOH} \text { for } 48 \mathrm{~h} \\
\text { presented the highest thermal stability. }\end{array}$ & [85] \\
\hline Cotton & LDPE & $\begin{array}{l}\text { Alkaline, silane, mixed } \\
\text { treatment, maleic anhydride, } \\
\text { and alkali-maleic anhydride }\end{array}$ & $\begin{array}{l}\text { The mixed treated composite } \\
\text { presented higher } T_{\mathrm{g}}\end{array}$ & [80] \\
\hline Jute & Epoxy & $\begin{array}{l}\text { Enzyme treatment, ozone } \\
\text { treatment and laser treatment }\end{array}$ & $\begin{array}{l}\text { The laser treated composites presented higher } \\
T_{\mathrm{g}} \text { values in relation to the other treatments. }\end{array}$ & [92] \\
\hline Pine cone & ABS & $\begin{array}{l}\text { Alkaline and bleaching } \\
\left.\quad \text { (alkaline }+\mathrm{H}_{2} \mathrm{O}_{2}\right)\end{array}$ & $\begin{array}{c}\text { The NaOH treatment increased the } T_{\mathrm{g}} \\
\text { of ABS/FT2\% and ABS/FT5\% composite } \\
\text { when compared to the pure ABS composite. } \\
\text { The untreated and ABS/FB2\% composites } \\
\text { showed no significant change in } T_{\mathrm{g}} \text {. }\end{array}$ & [93] \\
\hline Ramie & PLA & Maleic anhydride (MA) & $\begin{array}{l}\text { The thermal stability increased } \\
\text { but the } T_{g} \text { decreased }\end{array}$ & [94] \\
\hline
\end{tabular}

To summarize, using natural fibers with low lignin content leads to better thermal performance of composites. The thermal stability of fibers can be enhanced by removing a certain proportion of hemicelluloses and lignin constituents by different chemical treatments. The fiber modification techniques provide improved fiber-matrix interfacial adhesion, improved fiber roughness, and wettability and depend on the particular fiber/matrix used and the composite application. The thermal degradation of natural fibers 
is an important issue in the development of natural fiber reinforced composites in both manufacturing and for the use of these materials in service. In general, it was stated that in order to avoid the thermal degradation of developed NFRCs, the processing temperature must be kept below $250{ }^{\circ} \mathrm{C}$.

\subsection{Type of Matrix}

In natural fiber reinforced polymer composites, both thermoplastic and thermoset polymers are used as matrices. There are several types of thermoplastics such as polypropylene (PP), polyethylene (PE), nylon, polystyrene (PS), polyvinyl chloride (PVC), poly (methyl methacrylate) (PMMA), polytetrafluoroethylene (PTFE), polylactic acid (PLA), and acrylonitrile butadiene styrene (ABS), which can be used as matrix with natural fiber composites. When heated, thermoplastics soften and can be remoulded without significant degradation into a variety of products. Thus, their most important characteristic is the recyclability. They present other benefits, such as being lightweight, durable materials and they are reasonably priced $[41,95]$. The processing of natural fiber reinforced thermoplastic composites usually involves extrusion of materials at melt temperatures followed by shaping operations (i.e., injection molding and thermoforming). However, due to some degree of incompatibility of nonpolar hydrophobic PP and PE with polar and hydrophilic natural cellulose fibers, these types of resins are typically not used as matrices for NFRCs.

PLA is one of the most used thermoplastic polymers as a matrix in natural fiber composites. PLA is a widely used commercial biodegradable polymer, which belongs to one of the thermoplastic aliphatic polyesters produced from natural resources like corn, rice, and sugar beets [96]. PLA presents good stiffness, high strength, and low elongation at break, which make it an ecologically friendly material for composite applications [97]. However, the mechanical and thermal properties of PLA are strongly related to crystallinity. The wide application of PLA is limited by its low crystallization degree/rate, high brittleness and low thermal resistance (its thermal resistance is limited by its low glass transition $\left(60{ }^{\circ} \mathrm{C}\right)$ [98]). The thermal properties of natural fiber reinforced thermoplastic composites were studied by numerous researchers [41,99-106].

On the other hand, the thermoset matrices (epoxy, urethane, vinyl ester, phenolic, polyester, polyimide, polyurethane (PU)) can hardly be recycled or change the shape once the polymerization (curing) is concluded. The main thermoset resins used for natural fiber composites are epoxy and unsaturated polyesters [107]. Finally, biodegradable polymer matrices (elastomers, thermosets, and thermoplastics) are also used in the manufacture of NFRCs and combining these matrices with natural fibers produces "green composites" or "bio-composites". Biodegradable thermosets have gathered more interest in producing green composites in comparison to thermoplastics [108].

There is an intense effort in the scientific community to increase the performance of the thermoplastic biopolymers (mainly based on PLA matrices). Some examples of studies about the thermal properties of natural fiber reinforced green composites will be discussed in the next sections [109]. Some researchers performed comparative studies on the mechanical properties of epoxy and polyester composites reinforced with hemp fiber or sisal, jute, and curauá [19], in order to discover which of these thermoset matrices is more adequate for novel NFRCs to be used in technological applications. In general, the epoxy based NFRCs revealed superior mechanical and thermal properties to those of polyester NFRCs. In another study, the thermal properties of different NFRCs based on thermoplastic matrices (Acrylonitrile butadiene styrene (ABS), high impact polystyrene (HIPS), and high density polyethylene (HDPE)) reinforced with banana fiber were compared [110]. However, all these matrices have different chemical structures and undergo different reactions with the surface of natural fibers in composites. The thermal stability of composites is directly related to the crystallinity of the matrix and fiber reinforcements (high crystallinity improve the heat resistance). 


\subsection{Incorporation of Fillers, Fiber Content and Orientation}

It was shown in the literature that the presence of fillers, fiber content and orientation, and the manufacturing process of the composites also affects the thermal properties of composite materials [105,111-132].

The nature of fillers can be organic, inorganic metallic, and ceramic and they can be in macro, micro, or nano scale [133]. In general, superior thermal properties can be achieved with fillers at nano-scale, at low reinforcement concentration (usually $<10 \mathrm{wt} \%$ ). For instance, Ramesh et al. [114] investigated the effect of MMT clay filler in the thermal properties of Kenaf fiber-reinforced PLA composite. The kenaf fibers were treated with $6 \%$ of $\mathrm{NaOH}$ solution for $3 \mathrm{~h}$, and the amount of MMT used was $1 \%, 2 \%$, and $3 \%$. It was found that the presence of MMT clay improved the thermal stability. The MMT clay acts as a barrier, preventing the PLA polymer matrix from volatilizing. The segmental mobility of the polymer networks between the clay layers is limited, resulting in better thermal stability properties. Arulmurugan et al. [128] studied the effect of barium sulfate $\left(\mathrm{BaSO}_{4}\right)$ on the thermal properties of an aloevera/flax hybrid composite. The fibers were subjected to chemical pre-treatment (sodium hydroxide and potassium permanganate) with $10 \%$ and $5 \%$ for $1 \mathrm{~h}$, respectively. Then, they were treated with sodium laurel sulphate with $2 \%$ for $30 \mathrm{~min}$. The authors report that the increase in $\mathrm{BaSO}_{4}$ in the pure and hybrid composite increased the thermal resistance of hybrid natural reinforced polymeric. Moreover, the maximum peak for the treated composites shows an increment with the addition of $\mathrm{BaSO}_{4}$ in its structure. In a different study, Bhoopathi et al. [134], investigated the influence of eggshell nanoparticles on the thermal properties of hemp reinforced composites. The natural fibers were treated by mercerization ( $5 \%$ of $\mathrm{NaOH}$ for $5 \mathrm{~h}$ at room temperature). The studied cases were: Hemp without eggshell ( $\%$ ESP), hemp $+7 \%$ eggshell (7\%ESP), hemp $+14 \%$ eggshell (14\%ESP), hemp $+21 \%$ eggshell ( $21 \% \mathrm{ESP})$. The authors report that increasing the nanoparticle percentage increased the degradation temperature of the composites when compared to the unmodified composite samples. The best case found was the $14 \% \mathrm{ESP}$, where the maximum exothermic peak value of degradation temperature onset was $411.6{ }^{\circ} \mathrm{C}$ while for the unfilled case it was $326.2^{\circ} \mathrm{C}$. Gouda et al. [135] studied hybrid composites with bamboo and GNP filler and found that the hybrid composites exhibited improved thermal conductivity. DMA results showed that the $T_{g}$ of the hybrid composite materials lay in the range of $90-95^{\circ} \mathrm{C}$.

Sumesh et al. [116] investigated the thermal properties of cellulose micro filler (CMF) filled pineapple (PA)/flax (FL) hybrid composites and showed that the endothermic enthalpy and the endothermic peak increased due to the addition of CMF to the PA/FL composite. The improvement in the endothermic peak was from $92.99^{\circ}$ to $114.94^{\circ}$ for the $2 \%$ CMF and $30 \%$ PA/FL specimens, while the endothermic energy increased from $492.34 \mathrm{Jg}^{-1}$ to $499.39 \mathrm{Jg}^{-1}$. The $3 \% \mathrm{CMF}$ with $35 \%$ PA/FL specimens presented an increase in the endothermic peak from $92.56{ }^{\circ} \mathrm{C}$ to $120.39{ }^{\circ} \mathrm{C}$, while the enthalpy increased from $495.86 \mathrm{Jg}^{-1}$ to $504.21 \mathrm{Jg}^{-1}$. The untreated $30 \mathrm{wt} \% \mathrm{PA} / \mathrm{FL}$ with $2 \% \mathrm{CMF}$ presented lower enthalpy and endothermic peak due to the poor bonding capacity of untreated cellulose fibers.

Souza et al. [136] studied the effect of the percentage of fiber on the thermal characteristics of natural composites reinforced with caranan fiber. The studied variation of fiber/matrix percentage was from $0 \%$ to $30 \%$. The authors show that the increase of the caranan fiber increases the $T_{g}$ of the composites. The fiber contents with $20 \%$ and $30 \%$ had a $T_{g}$ value of $96^{\circ} \mathrm{C}$ and $113^{\circ} \mathrm{C}$, respectively. Devireddy et al. [137] studied the thermal properties of banana/jute epoxy hybrid composites. The transverse and longitudinal thermal conductivities of the hybrid composites decreased by $44.35 \%$ and $34.98 \%$, respectively, for $30 \mathrm{wt} \%$ jute and $10 \mathrm{wt} \%$ of banana fibers specimens. The thermal diffusivity and specific heat capacity of jute/banana hybrid composite decreased with increasing the fiber content. The combination of jute $(30 \mathrm{wt} \%)$ and banana $(10 \mathrm{wt} \%)$ presented the highest thermal stability at a higher temperature range. 


\section{Methods Used to Determine the Thermal Properties of Natural and Hybrid Composites}

Different methods are used to determine the thermal properties of natural and hybrid fiber composites and to help understand and determine the suitability of different fiber-reinforced composites for a certain application. The methods used in the literature for thermal analysis of composites are as follows: Thermogravimetric analysis (TGA), differential scanning calorimetry (DSC), and dynamic mechanical analysis (DMA). Figure 2 presents a summary of the main methods used to determine the thermal properties of composite materials with the main thermal properties of the composites provided by these techniques. This section presents an overview of the main techniques used for the thermal characterization of natural and hybrid fiber composites.

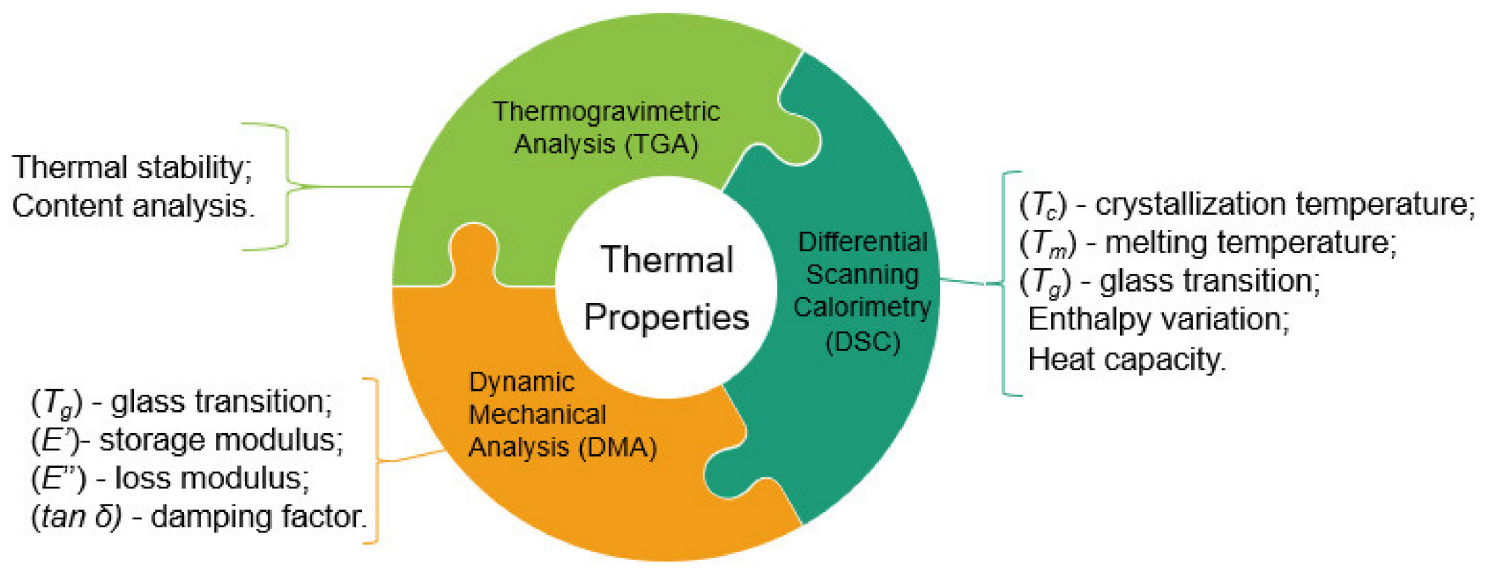

Figure 2. Schematic of the principal methods used to determine the thermal properties of composites. Reproduced with permission from [35].

\subsection{Thermogravimetric Analysis (TGA)}

TGA analysis consists of measuring the weight of a material sample as a function of temperature and/or time, in a specific controlled atmosphere (e.g., nitrogen, helium, air, or other gases) $[74,138,139]$. Different temperatures and measurement times are applied in accordance with the matrix type of the natural fiber composite sample [39]. Typical thermogravimetric parameters consist of moisture, volatile substances, loss on ignition, or ash. The thermal data obtained from TGA analysis are dependent on several parameters, such as the sample's mass and form, atmosphere, flow rate, heating rate, and the treatment applied [39]. For example, sample mass and form affect the profile of the TG curve. A big sample will possibly present thermal gradients in the sample, which will determine a temperature deviation from the set temperature due to endo- or exothermal reactions as well as a delay in mass loss.

As discussed in the previous section, the thermal behaviour of natural fiber composites depends on the principal constituents (natural fibers and matrix type) of the composite. For example, similar natural fibers, such as wood, jute, and sisal, present similar TG/DTG curves and thermal decomposition patterns. In general, the derivative thermogravimetric test (DTG) curve of natural fibers shows elimination of water and the thermal decomposition of cellulose components of the fibers. The DTG curve shows the maximum rate of peak thermal decomposition, and fiber constituents are indicated by peaks in each degradation range. For instance, the lignocellulose fibers (i.e., jute, flax, wood, sisal, ramie, curauá etc.) present three stages of degradation. The first stage is related to water loss by natural fiber $\left(60-100{ }^{\circ} \mathrm{C}\right)$. The second stage is related to the loss of the main constituents of the fibers: hemicellulose, cellulose, and lignin $\left(200-500{ }^{\circ} \mathrm{C}\right)$. Finally, the last stage of degradation is the formation of active coal as a form of residue [48,140-143].

Table 2 summarizes several studies which present the stages of decomposition of different natural fiber reinforced composites. 
Table 2. Stages of thermal degradation of natural fiber reinforced composites.

\begin{tabular}{|c|c|c|c|c|c|}
\hline Fiber Type & Matrix & Stage 1 & Stage 2 & Stage 3 & Ref. \\
\hline $\begin{array}{c}\text { Sisal, } \\
\text { Sisal + Ramie, } \\
\text { Sisal + Curauá }\end{array}$ & Epoxy & $\begin{array}{c}30-150{ }^{\circ} \mathrm{C}: \\
\text { evaporation of } \\
\text { humidity retained } \\
\text { in the fibers }\end{array}$ & $\begin{array}{c}240-420^{\circ} \mathrm{C}: \\
\text { pyrolysis process. }\end{array}$ & - & [107] \\
\hline Bamboo & $\begin{array}{l}\text { Epoxy, polyester, } \\
\text { vinyl ester }\end{array}$ & $\begin{array}{l}30-155{ }^{\circ} \mathrm{C}: \\
\text { evaporation of } \\
\text { moisture. }\end{array}$ & $\begin{array}{l}199-399^{\circ} \mathrm{C} \text { : } \\
\text { the decomposition of } \\
\text { cellulosic components } \\
\text { (cellulose and } \\
\text { hemicellulose). }\end{array}$ & $\begin{array}{l}364-499^{\circ} \mathrm{C}: \\
\text { the decomposition } \\
\text { of lignin. }\end{array}$ & [85] \\
\hline Sugar Palm & Phenolic & $\begin{array}{c}30-200{ }^{\circ} \mathrm{C}: \\
\text { corresponds to } \\
\text { vaporization of water } \\
\text { molecules }\end{array}$ & $\begin{array}{l}200-300{ }^{\circ} \mathrm{C}: \\
\text { the thermal } \\
\text { degradation of } \\
\text { the hemicellulose, } \\
\text { cellulose and lignin. }\end{array}$ & $\begin{array}{l}\text { 300-400 }{ }^{\circ} \mathrm{C} \text { : } \\
\text { the loss of } \\
\text { small groups and } \\
\text { water bonds in } \\
\text { the chains of the } \\
\text { chemical structures. }\end{array}$ & [53] \\
\hline Ramie and Buriti & Polyester & $\begin{array}{l}61^{\circ} \mathrm{C} \text { (Ramie)- } \\
69^{\circ} \mathrm{C} \text { (Buriti): } \\
\text { is attributed to the } \\
\text { water evaporating. }\end{array}$ & $\begin{array}{l}289{ }^{\circ} \mathrm{C} \text { (Ramie)- } \\
292{ }^{\circ} \mathrm{C} \text { (Buriti): } \\
\text { The decomposition of } \\
\text { amorphous } \\
\text { constituents, such as } \\
\text { hemicellulose. }\end{array}$ & $\begin{array}{c}368^{\circ} \mathrm{C} \text { (Ramie)- } \\
341^{\circ} \mathrm{C} \text { (Buriti): } \\
\text { Thermal } \\
\text { decomposition } \\
\text { of cellulose. }\end{array}$ & [84] \\
\hline Arundo donax $\mathrm{L}$. & Benzoxazine resin & - & $\begin{array}{l}200-300{ }^{\circ} \mathrm{C} \text { : } \\
\text { The decomposition of } \\
\text { hemicellulose } \\
\text { and cellulose. }\end{array}$ & $\begin{array}{l}350-500{ }^{\circ} \mathrm{C}: \\
\text { The decomposition } \\
\text { of lignin. }\end{array}$ & [144] \\
\hline Fique & $\begin{array}{l}\text { Linear Low-Density } \\
\text { Polyethylene } \\
\text { (LLDPE) and Epoxy }\end{array}$ & $\begin{array}{c}\quad 60-100^{\circ} \mathrm{C} \text { : } \\
\text { The evaporation of } \\
\text { superficial water. }\end{array}$ & $\begin{array}{l}250-350{ }^{\circ} \mathrm{C}: \\
\text { The decomposition of } \\
\text { hemicellulose. }\end{array}$ & $\begin{array}{c}350-600{ }^{\circ} \mathrm{C}: \\
\text { The decomposition } \\
\text { of } \alpha \text {-cellulose. }\end{array}$ & [145] \\
\hline Coir fiber & PLA & $\begin{array}{l}25-150{ }^{\circ} \mathrm{C}: \\
\text { attributed to } \\
\text { the evaporation } \\
\text { of water. }\end{array}$ & $\begin{array}{l}190^{\circ} \mathrm{C} \text { and } 290{ }^{\circ} \mathrm{C}: \\
\text { corresponds to the } \\
\text { hemicellulose } \\
\text { degradation. }\end{array}$ & $\begin{array}{l}290{ }^{\circ} \mathrm{C} \text { and } 360{ }^{\circ} \mathrm{C}: \\
\text { the thermal } \\
\text { degradation of } \\
\text { cellulose. The } \\
\text { degradation of lignin } \\
\text { occurred between } \\
280^{\circ} \mathrm{C} \text { and } 500{ }^{\circ} \mathrm{C}\end{array}$ & [146] \\
\hline $\begin{array}{l}\text { Kenaf and } \\
\text { Rice husk }\end{array}$ & PLA & $\begin{array}{l}30-150{ }^{\circ} \mathrm{C}: \\
\text { The evaporation } \\
\text { of the moisture } \\
\text { absorbed in fibers. }\end{array}$ & $\begin{array}{c}230-350{ }^{\circ} \mathrm{C}: \\
\text { The degradation } \\
\text { of the cellulosic } \\
\text { substances of } \\
\text { hemicelluloses, } \\
\text { cellulose and lignin. }\end{array}$ & - & [147] \\
\hline Sisal filler & Polyurethane (PU) & - & $\begin{array}{l}297^{\circ} \mathrm{C} \text { : } \\
\text { the hemicellulose } \\
\text { degradation. }\end{array}$ & $\begin{array}{l}365^{\circ} \mathrm{C}: \\
\text { corresponded } \\
\text { to cellulose } \\
\text { degradation }\end{array}$ & [148] \\
\hline Carpinus betulus L. & Polypropylene (PP) & - & $\begin{array}{l}223-290{ }^{\circ} \mathrm{C}: \\
\text { the hemicellulose } \\
\text { degradation. }\end{array}$ & $\begin{array}{c}290-380^{\circ} \mathrm{C}: \\
\text { the cellulose and } \\
\text { lignin degradation }\end{array}$ & [149] \\
\hline
\end{tabular}

Several authors used the thermogravimetric analysis to determine the thermal properties of natural fiber composites [52,53,84,85,104,107,128,150-152]. For example, Boopalan et al. [153] studied the thermal properties of jute (J)/banana (B) reinforced epoxy composites. The TGA analysis showed that the combinations of J (50\%)/B (50\%), J (75\%)/ $\mathrm{B}(25 \%)$, and J (25\%)/B (75\%) presented initial weight loss at $200{ }^{\circ} \mathrm{C}$ due to solvent removal 
in the epoxy matrix and major weight loss occurs at $380{ }^{\circ} \mathrm{C}(75.64 \%), 377.72{ }^{\circ} \mathrm{C}(82.14 \%)$, and $376.51^{\circ} \mathrm{C}(79.01 \%)$, respectively. However, the J/Epoxy and B/Epoxy presented the initial weight loss at $190{ }^{\circ} \mathrm{C}$ because of solvent removal from the matrix and major weight loss at $376.51{ }^{\circ} \mathrm{C}(79.01 \%)$ and $377.72{ }^{\circ} \mathrm{C}(74.43 \%)$, mainly due to epoxy and fiber volatilization and degradation. Therefore, the $50 \%$ jute and $50 \%$ banana fiber epoxy hybrid composite showed better thermal properties than other combinations.

Hidalgo-Salazar et al. [145], studied the thermal properties of fique fiber reinforced natural composites. Two types of resins (linear low-density polyethylene (LLDP) and epoxy resin (EP)) were used. Figure 3 presents an example of representative TG (Figure 3a) and DTG (Figure 3b) curves of the Fique fiber, which show that degradation occurred at $296{ }^{\circ} \mathrm{C}$, while the neat EP starts its decomposition at $96{ }^{\circ} \mathrm{C}$. Therefore, the EP/Fique samples degraded after the neat resin in both degradation steps. This has been previously reported in the available literature regarding EP/Phormium tenax leaf fiber composites and was explained to be due to an enhanced fiber/matrix interface [154]. The residual char after final degradation was $6.1 \%$ for neat epoxy resin and $11.1 \%$ for epoxy-Fique natural fiber composite. The authors state that this increase in the residual char of the composite was due to the Fique fiber incorporation in the epoxy resin.
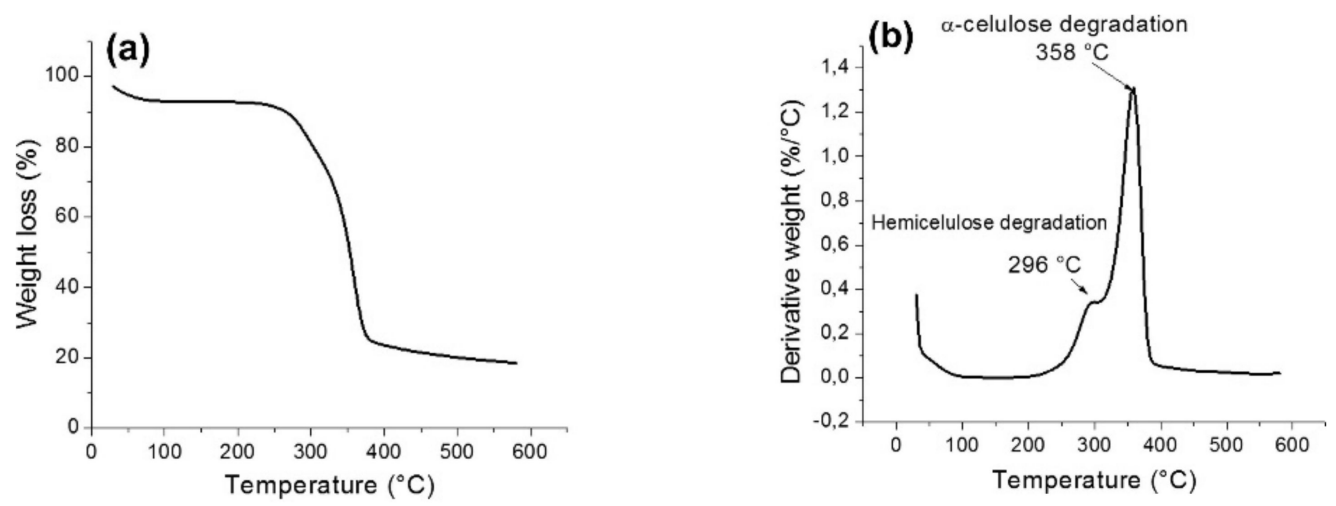

Figure 3. (a) TG and (b) DTG curves of Fique fibers at heating rates of $10^{\circ} \mathrm{C} / \mathrm{min}$. Reproduced with permission from [145].

Figure 4 presents an example of representative TG and DTG curves of LLDPE, LLDPE/Fique, while Figure 5 shows the thermal curves for EP and EP/Fique natural composites, respectively. For the neat LLDPE sample a single step degradation was observed with $T_{o}$ (onset) at $439{ }^{\circ} \mathrm{C}$ and $T_{\max }$ and $478^{\circ} \mathrm{C}$, respectively (see Figure $4 \mathrm{a}$ ). The char residue at the end of the degradation was $4.1 \%$. For the PE/Fique case, a two-step degradation process was observed. The authors state that the first degradation step is linked to the fiber constituent degradation $\left(T_{o}\right.$ at $\left.266^{\circ} \mathrm{C}\right)$ presenting a mass loss of $21 \%$. A minor decrease on the thermal stability of the polymeric matrix was observed, which can be linked to the degradation of fibers on the LLDPE during the thermocompression process at $170{ }^{\circ} \mathrm{C}$. Moreover, the residual weight of LLDPE-Fique increased to 5.6\%, due to the Fique fiber addition. In Figure $4 b$, it can be seen that the DTG curve presented two $T_{\text {max }}$ peaks at $293^{\circ} \mathrm{C}$ and $358{ }^{\circ} \mathrm{C}$, which can be linked to hemicellulose and $\alpha$-cellulose degradation. The second degradation step is related to LLDPE matrix decomposition. The process starts at $437^{\circ} \mathrm{C}$ and presented a $T_{\max }$ of $470{ }^{\circ} \mathrm{C}$. On the other hand, a two-stage weight loss process was reported for both EP and EP/Fique composites, indicating similar thermal degradation behaviour (see Figure 5). The first degradation step $\left(90{ }^{\circ} \mathrm{C}\right.$ to $200{ }^{\circ} \mathrm{C}$ ) is related to small molecular decomposition of EP. For this stage, the reported $T_{o}$ were $96^{\circ} \mathrm{C}$ and $114^{\circ} \mathrm{C}$, while $T_{\max }$ were $167^{\circ} \mathrm{C}$ and $165^{\circ} \mathrm{C}$ for $\mathrm{EP}$ and $\mathrm{EP} /$ Fique, respectively. In addition, the second degradation step $\left(250-500^{\circ} \mathrm{C}\right)$ illustrates the decomposition of the main polymeric chain. In this step, the observed $T_{o}$ was $344{ }^{\circ} \mathrm{C}$ and $352{ }^{\circ} \mathrm{C}$ while $T_{\max }$ was $365^{\circ} \mathrm{C}$ and $373^{\circ} \mathrm{C}$ for EP and EP-Fique, respectively. 

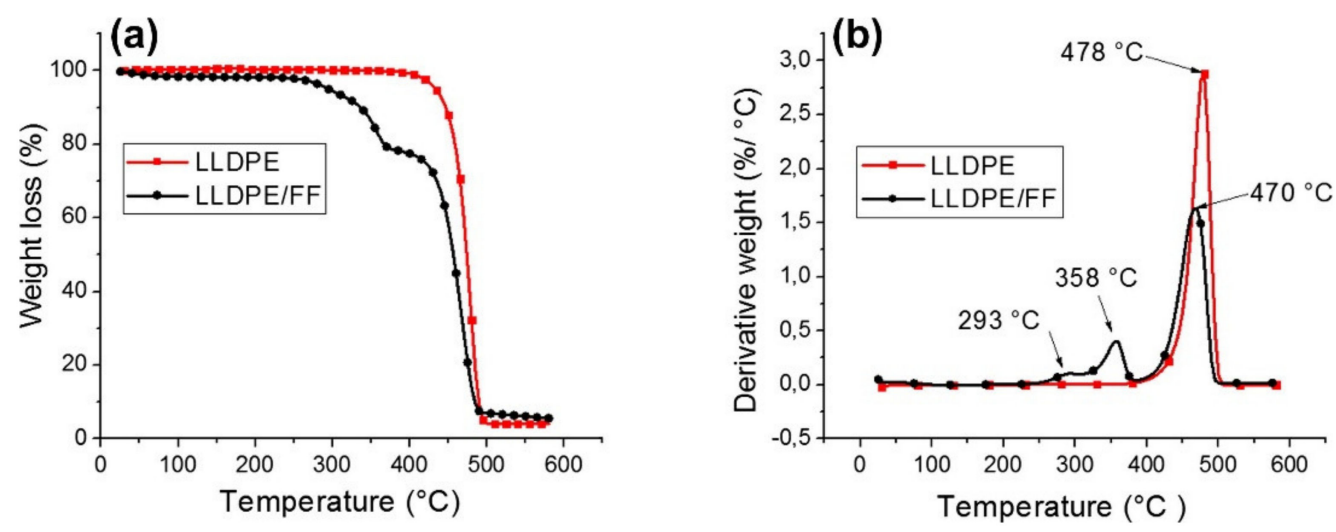

Figure 4. (a) TG curve of neat Linear Low-Density Polyethylene (LLDPE) and (b) DTG curve of Linear Low-Density Polyethylene nonwoven Fique Fiber natural composite (LLDPE/FF). Reproduced with permission from [145].
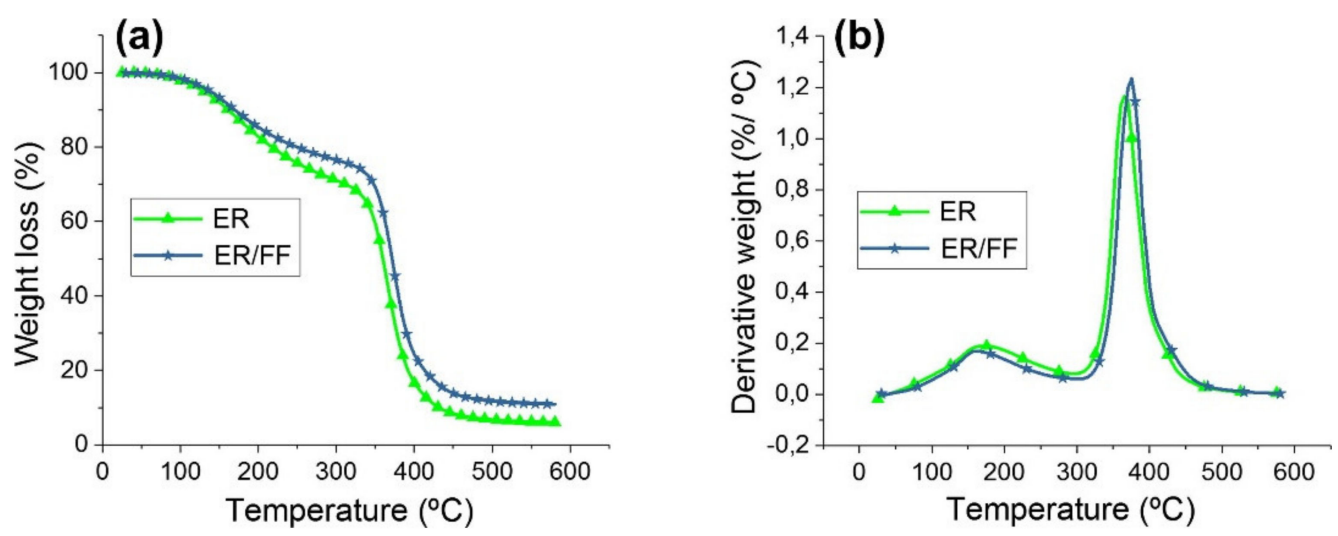

Figure 5. (a) TG and (b) DTG curves of neat Epoxy resin (EP) and Fique biocomposite based Epoxy (EP/FF). Reproduced with permission from [145].

Neher et al. [155], investigated the thermal properties of the palm fiber reinforced composite of acrylonitrile butadiene styrene (ABS). The composites were manufactured using an injection moulding machine in different weight fractions: 5, 10, and $20 \mathrm{wt} \%$. They found that thermal degradation occurs only in one stage for ABS $(100 \%)$, while the ABS composite with $10 \%$ of fiber presented higher $T_{\text {onset }}$ when compared to other reinforced cases. In a recent study, Komal et al. [156] investigated the thermal properties of short banana fiber/PLA fabricated by different processing techniques (injection molding (DIM), extrusion injection molding (EIM), and extrusion compression molding (ECM)). In Figure $6 a$, it can be seen that all the composites exhibited a similar trend of thermal decomposition. Figure $6 \mathrm{~b}$ shows that all the composites lost $5 \%, 25 \%, 50 \%$, and $75 \%$ of their weight in the temperature range of $275-285^{\circ} \mathrm{C}, 315-320^{\circ} \mathrm{C}, 350-355^{\circ} \mathrm{C}$, and $620-625^{\circ} \mathrm{C}$, respectively. Similar to the other studies discussed above (see Table 1), the loss of weight of the composites studied can be divided into three stages: 1 . The loss of weight at around $80-160{ }^{\circ} \mathrm{C}$ attributed to the evaporation of moisture present in the banana fiber; 2 . The weight reduction in the temperature range of $250-350{ }^{\circ} \mathrm{C}$ due to the decomposition of hemicellulose, cellulose, and some portion of the lignin of the banana fiber and pyrolysis of the PLA; 3 . The weight loss at the temperature range of $350-450{ }^{\circ} \mathrm{C}$ due to the pyrolysis of remaining lignin and pyrolysis of the residue of lignin and PLA. DTG curves (Figure 6c) show the precise peak position of the degradation temperature (maximum reduction in weight between $250{ }^{\circ} \mathrm{C}$ and $350{ }^{\circ} \mathrm{C}$ ), which represents the pyrolysis of the hemicellulose and cellulose of the fiber and PLA. 

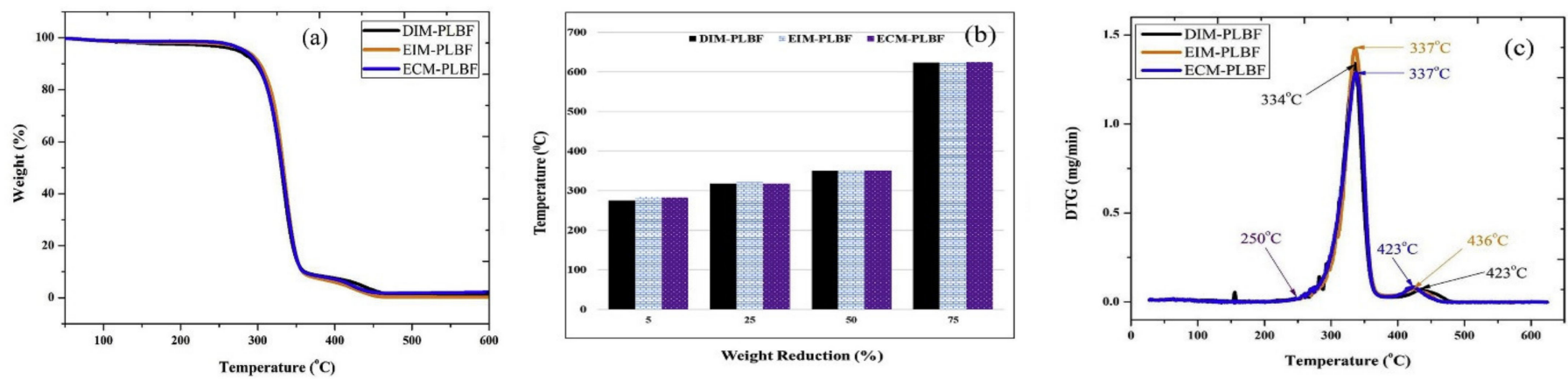

Figure 6. (a) TGA (b) mass reduction and (c) DTG curves of banana/PLA based composites fabricated using three processing techniques (DIM, EIM and ECM). Reproduced with permission from [156].

Table 3 summarizes the results from several recent studies on the thermal properties of natural fiber composites.

Table 3. Thermal properties of natural fiber composites obtained from TGA analysis.

\begin{tabular}{|c|c|c|c|}
\hline Fiber & Matrix & Thermal Properties & Ref. \\
\hline \multicolumn{4}{|c|}{ Thermoset matrices } \\
\hline Bamboo & $\begin{array}{l}\text { Epoxy, Polyester } \\
\text { and Vinyl ester }\end{array}$ & $\begin{array}{l}\text { The incorporation of bamboo fiber did not present a substantial improvement } \\
\text { in the initial onset degradation temperature }\left(T_{\text {onset }}\right) \text { of the composites. }\end{array}$ & [85] \\
\hline Fique & $\begin{array}{l}\text { Linear Low-Density } \\
\text { Polyethylene (LLDP) } \\
\text { and Epoxy resin (EP) }\end{array}$ & $\begin{array}{l}\text { The incorporation of the fique fiber in LLDP matrix decreased the } T_{\text {onset }} \\
\text { and } T_{\max } \text { when compared to pure LLDP composite. For the EP, the fiber } \\
\text { incorporation increased in } T_{\text {onset }} \text { and } T_{\max } \text { compared to the pure epoxy case. }\end{array}$ & [145] \\
\hline Buriti and ramie & Polyester & $\begin{array}{l}\text { The maximum peak of degradation temperature }\left(T_{d}\right) \text { for the ramie fiber } \\
\text { reinforced composite was } 372{ }^{\circ} \mathrm{C} \text {, while for the buriti composite it was } 346^{\circ} \mathrm{C} \text {. }\end{array}$ & [84] \\
\hline $\begin{array}{l}\text { Sisal, sisal + } \\
\text { curauá and sisal + } \\
\text { ramie }\end{array}$ & Epoxy & $\begin{array}{l}\text { The hybridization increased the thermal stability of the } \\
\text { composites when compared to the pure sisal composites. }\end{array}$ & [107] \\
\hline $\begin{array}{l}\text { Banana, jute } \\
\text { Banana + jute }\end{array}$ & Epoxy & $\begin{array}{l}\text { The thermal diffusivity and specific heat capacity of jute/banana } \\
\text { hybrid composite decreased with increasing the fiber content. }\end{array}$ & [137] \\
\hline Sugar Palm & Phenolic & The chemical treatment negatively affected the thermal stability of the composite. & [53] \\
\hline Sisal and kenaf & Polyester & $\begin{array}{l}\text { The thermal stability of hybrid composites was } \\
\text { superior when compared to the neat fiber case }\end{array}$ & [150] \\
\hline $\begin{array}{l}\text { Sugar palm fiber } \\
\text { (SPF) and roselle } \\
\text { fiber (RF) }\end{array}$ & Polyurethane & $\begin{array}{l}\text { The sugar palm fiber (SP) improved thermal stability of hybrid } \\
\text { composite. The roselle }(25 \mathrm{wt} \%)+\text { sugar palm }(75 \mathrm{wt} \%) \text { composite } \\
\text { showed higher thermal stability when compared to RFT composite. }\end{array}$ & [104] \\
\hline $\begin{array}{l}\text { Jute, jute }+ \\
\text { sisal and jute }+ \\
\text { curauá }\end{array}$ & $\begin{array}{l}\text { Epoxy and } \\
\text { Polyester }\end{array}$ & $\begin{array}{l}T_{\text {onset }} \text { was higher for the jute, jute }+ \text { curauá epoxy composites compared to polyester } \\
\text { composites. For jute }+ \text { sisal there was no significant change in } T_{\text {onset }} \text { for both matrices. }\end{array}$ & [19] \\
\hline Kenaf + pineapple & Phenolic & The treatment increased the maximum degradation temperature $\left(T_{d}\right)$. & [52] \\
\hline Curauá & Polyester & $\begin{array}{l}\text { The addition of the fiber and chemical treatment of fibers } \\
\text { with } \mathrm{NaOH} \text { improved the thermal stability of the composites. }\end{array}$ & [86] \\
\hline Mulberry & Polyester & The thermal stability of the composites increased by increasing the $\mathrm{NaOH}$ concentration. & [82] \\
\hline $\begin{array}{l}\text { Jute }+ \\
\text { Oil palm }\end{array}$ & Epoxy & $\begin{array}{l}\text { The hybridization of the composites increased the maximum } \\
\text { degradation temperature when compared to the pure Oil palm composite. }\end{array}$ & [141] \\
\hline $\begin{array}{l}\text { Date palm fibers } \\
\text { (DPF) }\end{array}$ & Epoxy & $\begin{array}{l}\text { DPF improves the thermal stability of the composite. } E^{\prime} \text { and } E^{\prime \prime} \text { increased } \\
\text { (50\% DPF presented higher improvement compared to } 40 \% \text { and } 60 \% \text { DPF content). }\end{array}$ & [157] \\
\hline
\end{tabular}


Table 3. Cont.

\begin{tabular}{|c|c|c|c|}
\hline Fiber & Matrix & Thermal Properties & Ref. \\
\hline \multicolumn{4}{|c|}{ Thermoplastic matrices } \\
\hline Banana & $\begin{array}{l}\text { ABS, high impact } \\
\text { polystyrene (HIPS) } \\
\text { and HDPE }\end{array}$ & $\begin{array}{l}\text { The addition of natural fiber to the thermoplastic matrix showed } \\
\text { an increased thermal stability when compared to the pure resin. }\end{array}$ & [110] \\
\hline Date palm & PVC and HDPE & $\begin{array}{l}\text { The chemical treatment improved the } T_{\text {onset }} \text { and } T_{\max } \text { of the date palm reinforced } \\
\text { composites when compared to the untreated composite and the pure matrix. }\end{array}$ & [70] \\
\hline $\begin{array}{l}\text { Basalt }+ \text { Cissus } \\
\text { quadrangularis }\end{array}$ & PLA & The addition of basalt fiber increased the thermal stability of the composite. & [158] \\
\hline Jute & PLA & $\begin{array}{l}\text { The configuration 2J5P-2 (2 layers of jute and } 5 \text { layers of PLA) of composite } \\
\text { showed an increase in } T_{\text {onset }} \text { and } T_{\max } \text { when compared to the other cases. }\end{array}$ & [152] \\
\hline Wood powder & Polypropylene (PP) & $\begin{array}{l}\text { The incorporation of wood powder presented maximum temperature }\left(482.3^{\circ} \mathrm{C}\right) \\
\text { for } 45 \mathrm{wt} \% \text { when compared to pure PP composite }\left(475.3^{\circ} \mathrm{C}\right) .\end{array}$ & [159] \\
\hline Flax + Basalt & PLA & $\begin{array}{l}\text { The hybridization of the composite showed an increase in } T_{\text {onset }} \\
\text { when compared to the flax + PLA composite. The increment of } \\
\text { basalt fiber increased the thermal stability of the composite. }\end{array}$ & [151] \\
\hline Banana & PLA & $\begin{array}{l}\text { The presence of banana fibers in PLA matrix led to a reduction in degradation } \\
\text { temperature as compared to neat PLA, which was attributed to the low } \\
\text { thermal stability of banana fibers that possibly enhanced deformation } \\
\text { of the crystalline structure of PLA at higher temperatures. }\end{array}$ & [57] \\
\hline $\begin{array}{l}\text { Jute + Maleic } \\
\text { anhydride } \\
\text { (MAPP) }\end{array}$ & Polypropylene (PP) & $\begin{array}{l}\text { The incorporation of MAPP did not have significant } \\
\text { influence on the thermal stability of the composites. }\end{array}$ & [160] \\
\hline $\begin{array}{c}\text { Kenaf }+ \\
\text { epoxidized } \\
\text { jatropha oil (EJO) }\end{array}$ & PLA & $\begin{array}{l}\text { The incorporation of EJO ( } 5 \mathrm{wt} \%) \text { slightly increased the thermal } \\
\left.\left.\text { stability ( } T_{\text {onset }} \text { and } T_{\text {end }}\right) \text { of composites when compared to EJO (1 wt } \%\right) \text {. }\end{array}$ & [161] \\
\hline Sisal & Polyurethane (PU) & $\begin{array}{l}\text { The chemical treatment improved the thermal } \\
\text { stability when compared with untreated composite. }\end{array}$ & [148] \\
\hline Carpinus betulus L. & Polypropylene (PP) & The addition of fiber lowered the thermal stability when compared with pure PP matrix. & [149] \\
\hline
\end{tabular}

\subsection{Differential Scanning Calorimetry (DSC)}

The DSC determines the material transitions as a function of temperature and time. The endothermic (heat absorption) and exothermic (heat released) peaks and magnitudes indicate the thermal phase transformation of the composites $[162,163]$. The principal thermal data extracted from this analysis are the glass-transition temperature $\left(T_{g}\right)$, degree of crystallization $\left(X_{c}\right)$, crystallization temperature $\left(T_{c}\right)$, and fusion temperature $\left(T_{m}\right)$. The enthalpy variation and heat capacity of the composite can also be determined.

The $T_{g}$ is an important material property when considering the natural composites for a particular end-use application. $T_{g}$ is the temperature band in which a thermoset polymer shifts from a stiff to a more flexible or rubbery state. It is well known that the "normal" state of most thermoset polymers at room temperature is rigid (amorphous solid). Below the $T_{g}$, the molecular chains of the thermoset resins do not present enough energy to let them move around (the molecules are frozen in place as a rigid structure because of the short chain length, molecular groups separating off the chain, and interlocking with each other). Moreover, when the polymer resin is heated, the molecules of the polymer resin gain energy and they can start to move around. The amorphous rigid structure of the thermoset polymer resin is transformed to a flexible structure (rubbery state) when a certain heat energy level is attained, and the polymer molecules are allowed to move freely around each other. This transition point is termed the glass transition temperature. To conclude, the service temperature of polymer resins should be always below the $T_{g}$. If the composites are used above their $T_{g}$, they will quickly lose their mechanical properties (strength and stiffness), and they will continue to maintain some mechanical properties until the temperature reaches $T_{m}$. The crystallization temperature $\left(T_{c}\right)$ is associated with the point where polymer chain alignment modification is possible. Upon reaching the $T_{c}$, ordered crystalline chain regions appear, called lamellae. However, amorphous regions still 
remain in the structure. It should be noted that the crystallization is an exothermic peak in a DSC curve. $T_{\mathcal{C}}$ temperature is higher than $T_{g}$ but still lower than that of the melting temperature, $\left(T_{m}\right)$. Finally, the melting temperature $\left(T_{m}\right)$ is the point where the polymeric chains lose their bonds and turn into a liquid. This process is called endothermic transition. In general, $T_{m}$ for a thermoset polymer is higher than its $T_{g}$. At temperatures above $T_{g}$ but below $T_{m}$, the polymer resin is in the rubbery state and the material can exhibit large deformations under a relatively low load.

There are several factors that can affect the data collected by the DSC analysis, such as sample size and shape, heat ramp, and type of atmosphere. Several authors used the DSC technique to investigate the thermal stability of natural fiber and hybrid composites $[66,86,107,116,134,136,159,164-166]$. For instance, Gupta et al. [164], used the DSC technique to investigate the effect of hybridization on the thermal properties of jute/sisal fibers in epoxy-based composites. The studied cases were: jute (J1), sisal (S1), $50 \%$ of jute $+50 \%$ of sisal (H1), $25 \%$ of jute $+75 \%$ of sisal $(\mathrm{H} 2)$ and $75 \%$ of jute $+25 \%$ of sisal (H3). The composites were manufactured using the hand-lay-up technique and total fiber loading of $30 \% \mathrm{wt}$. They found that hybridization positively affected the $T_{g}$ of the composites. The values of $T_{g}$ found for $\mathrm{H} 1$ samples was $73.86{ }^{\circ} \mathrm{C}$, for the $\mathrm{H} 2$ case was $72.86^{\circ} \mathrm{C}$, while for $\mathrm{H} 3$ the $T_{g}$ value found was $68.36^{\circ} \mathrm{C}$ when compared with the $T_{g}$ of the matrix $\left(65.16^{\circ} \mathrm{C}\right)$. Moreover, the exothermic temperature $\left(T_{d}\right)$ for hybrid composites and natural fibers presented higher values than the pure matrix.

Pereira et al. [107] used DSC to investigate the influence of the hybridization on the thermal properties of pure sisal and epoxy hybrid composites. Figure 7 shows the DSC curves for the composites studied. It can be seen that two events predominate, endothermic and exothermic around $100^{\circ} \mathrm{C}$ and $375^{\circ} \mathrm{C}$, respectively. Sisal + curauá was the sample that absorbed the greatest heat in the endothermic event and the one that least released heat in the exothermic event.

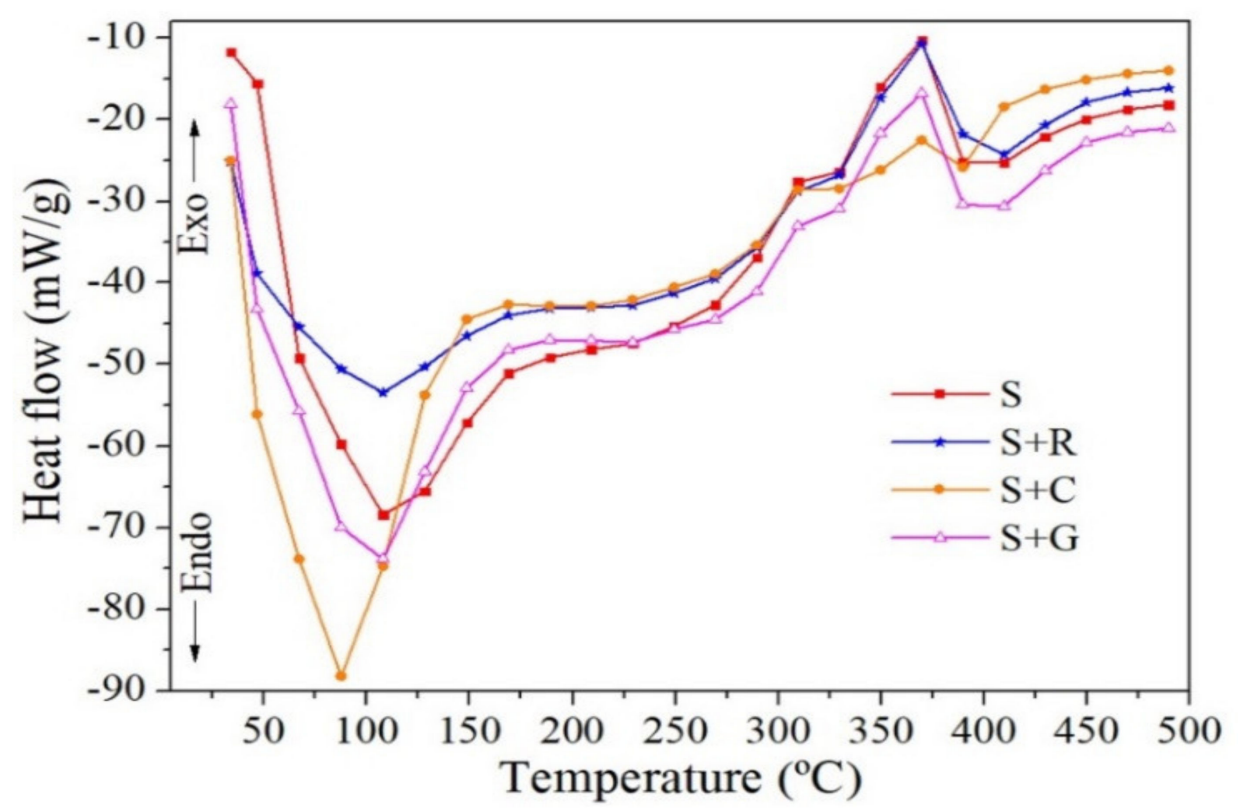

Figure 7. DSC curves of epoxy sisal based composites as a function of hybridization (S-Sisal; S + R-Sisal + ramie; S + C-Sisal + curauá and S + G-sisal + glass fiber), Reproduced with permission from Pereira et al. [107].

Table 4 summarizes the results from several recent studies on the thermal properties of natural fiber composites obtained from DSC analysis. 
Table 4. Thermal properties of natural and hybrid composites obtained from DSC analysis.

\begin{tabular}{|c|c|c|c|}
\hline Fiber & Matrix & Thermal Properties & Ref. \\
\hline \multicolumn{4}{|c|}{ Thermoset Matrices } \\
\hline Curauá & Polyester & $\begin{array}{l}\text { The chemical treatments used increased the } T_{g} \text { of the composites. } \\
\text { The best treatment was } \mathrm{Ca}(\mathrm{OH})_{2} \text { with a } T_{g} \text { value of } 141.92{ }^{\circ} \mathrm{C} \text {. }\end{array}$ & [86] \\
\hline Jute $+\mathrm{ZrO}_{2}$ & Polyester & The presence of the nanofiller increased the $T_{g}$ of the composite. & [165] \\
\hline Jute+ ramie & Epoxy & $\begin{array}{l}\text { Alkalization and mixed (alkalization + silane) } \\
\text { treatment increased the thermal properties. }\end{array}$ & [65] \\
\hline Caranan & Epoxy & $\begin{array}{l}\text { The endothermic peak shows a large } \\
\text { amount of water retained in the fiber. }\end{array}$ & [136] \\
\hline Jute + sisal & Epoxy & $\begin{array}{l}\text { The addition of natural fiber produced } \\
\text { an increase of thermal properties }\left(T_{g} \text { and } T_{c}\right) \text {. }\end{array}$ & [164] \\
\hline Hemp+ eggshell & Epoxy & $\begin{array}{l}\text { The incorporation of filler reduced } \\
\text { the exothermic peak of the composite. }\end{array}$ & [134] \\
\hline $\begin{array}{c}\text { Flax + Pineapple } \\
+ \text { Micro Cellulose (CMF) }\end{array}$ & Epoxy & $\begin{array}{l}\text { The addition of CMF improved the endothermic peak } \\
\text { and enthalpy when compared to the unmodified composite. }\end{array}$ & [116] \\
\hline Kenaf + Sisal & Bio-Epoxy & UV aging increased the $T_{g}$ of hybrid composites and pure fibers. & [166] \\
\hline Jute + coir & Epoxy & The endothermic peak showed water loss between $60-120^{\circ} \mathrm{C}$. & [167] \\
\hline $\mathrm{Flax}+\mathrm{TiO}_{2}$ & Epoxy & $\begin{array}{l}\text { The addition of } 0.7 \% \text { of nanofiller increased the } T_{g} \\
\text { by } 5{ }^{\circ} \mathrm{C} \text { when compared to the unfilled composite. }\end{array}$ & [168] \\
\hline \multicolumn{4}{|c|}{ Thermoplastic matrices } \\
\hline Cotton & $\begin{array}{l}\text { Low-density } \\
\text { polyethylene (LDPE) }\end{array}$ & $\begin{array}{l}\text { The mixed (alkali-silane) treated composite presented higher } \\
\text { values for } T_{g} \text { when compared with other chemical treatments. }\end{array}$ & [80] \\
\hline Bamboo & Polypropylene (PP) & $\begin{array}{l}\text { The incorporation of natural fiber and nanofiller }\left(\mathrm{TiO}_{2}\right) \\
\text { improved the crystallization temperature }\left(T_{c}\right) \\
\text { when compared to pure PP composite. }\end{array}$ & [169] \\
\hline Pine cone (Pinus elliottii) & ABS & $\begin{array}{l}\text { The chemical treatment }(\mathrm{NaOH}) \text { increased the } T_{g} \\
\text { of the composite when compared to pure ABS composite. }\end{array}$ & [93] \\
\hline Wood powder & Polypropylene (PP) & $\begin{array}{l}\text { The addition of wood powder }(15 \mathrm{wt} \% \text { and } 30 \mathrm{wt} \%) \text { showed no } \\
\text { significant change for the melting temperature }\left(T_{m}\right) \text {. However, } \\
\text { the composite with } 45 \mathrm{wt} \% \text { presented a decrease of } 2{ }^{\circ} \mathrm{C} \text { in } T_{m} \text {. }\end{array}$ & [159] \\
\hline Bamboo & PLA & $\begin{array}{l}\text { The alkalinization treatment of bamboo fiber increases thermal } \\
\text { stability }\left(T_{g} \text { and } T_{c}\right) \text { when compared to untreated composites. }\end{array}$ & [170] \\
\hline Date palm & PVC and HDPE & $\begin{array}{l}\text { The chemical treatment }\left(\mathrm{H}_{2} \mathrm{O}_{2}+\mathrm{HNO}_{3}\right) \text { increased the } T_{g} \\
\text { of the date palm reinforced composite when } \\
\text { compared to the other treatments and the pure matrix. }\end{array}$ & [70] \\
\hline $\begin{array}{l}\text { Kenaf fiber; } \\
\text { up to } 10 \%(w / w) \text { of thymol }\end{array}$ & PLA & $\begin{array}{l}\text { No change in } T_{g} \text { with an increase in kenaf fiber content unless } \\
\text { when plasticizer is used. A decrease in all of the key thermal } \\
\text { transitions with the addition of } 5 \% \text { and } 10 \%(w / w) \text { thymol } \\
\text { into the neat PLA and PLA/kenaf composites was found. }\end{array}$ & [171] \\
\hline Coir fibers & PLA & $\begin{array}{l}\text { Addition of coir fibers increased the } T_{\mathrm{g}} \text { and degree of } \\
\text { crystallinity while the crystallization temperature decreased. }\end{array}$ & [172] \\
\hline Coir fibers & PLA & $\begin{array}{c}\text { Addition of coir fibers in PLA matrix does not affect the } T_{g} \\
\text { and melting temperatures of the coir fiber-reinforced PLA. } \\
\text { However, the cold crystallization temperatures } \\
\text { decreased with increasing fiber content }\end{array}$ & [146] \\
\hline $\begin{array}{l}\text { Basalt }+ \text { Cissus } \\
\text { quadrangularis }\end{array}$ & PLA & $\begin{array}{c}\text { The PBC2 (PLA }+12 \mathrm{wt} \% \text { of basalt }+ \\
0.5 \mathrm{wt} \% \text { of Cissus quadrangularis) composite } \\
\text { showed maximum } T_{g}=58.72{ }^{\circ} \mathrm{C} \text { and } X_{c}=24.43 \%\end{array}$ & [158] \\
\hline
\end{tabular}




\subsection{Dynamic Mechanical Analysis (DMA)}

DMA determines the following thermal data: storage modulus $\left(E^{\prime}\right)$, loss modulus $\left(E^{\prime \prime}\right)$, damping factor $\left(\tan \delta=E^{\prime \prime} / E^{\prime}\right)$ and glass transition temperature $\left(T_{g}\right)$ [173]. The storage modulus $\left(E^{\prime}\right)$ is associated with the energy storage of the elastic characteristics of the material $[66,111,174,175]$. It decreases with increasing the temperature and is associated with "stiffness" of the composites sample [111,174]. The loss modulus (E") is linked to the energy dissipation promoted by the viscous part of the composite sample. This dissipation is related to the internal molecular friction of the molecular chains due to the following factors: morphological transformation and relaxation, morphology, and system heterogeneity $[39,111]$. The damping factor is defined by dividing the storage and loss modulus $\left(\tan \delta=E^{\prime \prime} / E^{\prime}\right)$ and is associated with the internal mobility of the polymeric molecular chains, showing the influence of the fiber/matrix interactions $[65,111,175,176]$. A high $\tan \delta$ value indicates that the system is dissipating more energy than it is storing due to the fiber-matrix interaction quality, while a low $\tan \delta$ value suggests that the polymeric chain has lower mobility showing a good fiber/matrix interfacial interaction. Determining $T_{g}$ using DMA measurements of the complex modulus is usually performed as temperature increases with a constant heating rate.

In the DMA analysis, several different test method configurations are available (i.e., dual cantilever, single cantilever, three-point bending, torsion, shear, tension, and compression). However, the most common test method for composite materials is the three-point bending mode, as it removes the combined loading present in single or double cantilever modes and yields measurable strains in relatively rigid materials. Depending on the methodology used, significant variation of the glass transition temperature for a given material may be reported via the DMA analysis (up to $25^{\circ} \mathrm{C}$ ). The calculation method may also be more or less conservative, taking the $T_{g}$ via first inflection point/modulus drop onset or the $\tan \delta$ peak, respectively [177].

The thermal properties of the natural fiber composites collected via DMA depends on the physical or structural arrangement of phases (interface), morphology and the nature of natural composite constituents. It was shown in the literature that the presence of fillers, fiber content and orientation, and the chemical treatment of the fibers affect the dynamic mechanical properties of a composite material $[110,111]$. The mode of testing also has an influence on the DMA tests results.

The DMA analysis was used by several researchers to determine the thermal properties of natural fiber composites [52,65,71,82,164,166,178]. For example, Chee et al. [179] used the thermomechanical analysis (TMA) and DMA analysis to investigate the effect of the hybridization of bamboo (B) and Kenaf (K) fibers on the thermal properties of various configurations in epoxy resin-based hybrid composites. The authors reported that the composite with $100 \%$ Bamboo obtained a value of storage modulus $\left(E^{\prime}\right)$ of $979 \mathrm{MPa}$, while the epoxy resin and 100\% Kenaf had a value of 449 and $775 \mathrm{MPa}$, respectively.

Komal et al. [156] used DMA to study the thermal properties of short banana fiber (20 $\mathrm{wt} \%$ ) and PLA matrix fabricated using different processing techniques (direct injection molding (DIM), extrusion injection molding (EIM), and extrusion compression molding $(\mathrm{ECM})$ ). They found that the dynamic mechanical properties (storage modulus, loss modulus, and tan delta) and crystallinity of the composites fabricated by EIM presented a significant improvement compared to the other fabrication techniques, as can be seen in Figure 8.

Table 5 summarizes the results from several recent studies on the thermal properties of natural fiber and hybrid composites obtained through DMA analysis. 


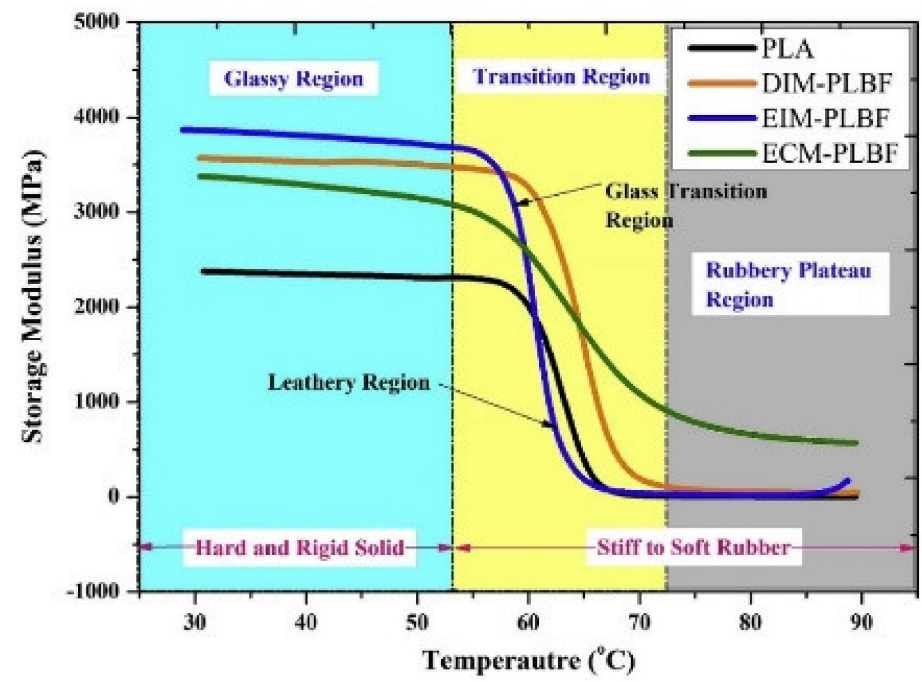

(a)

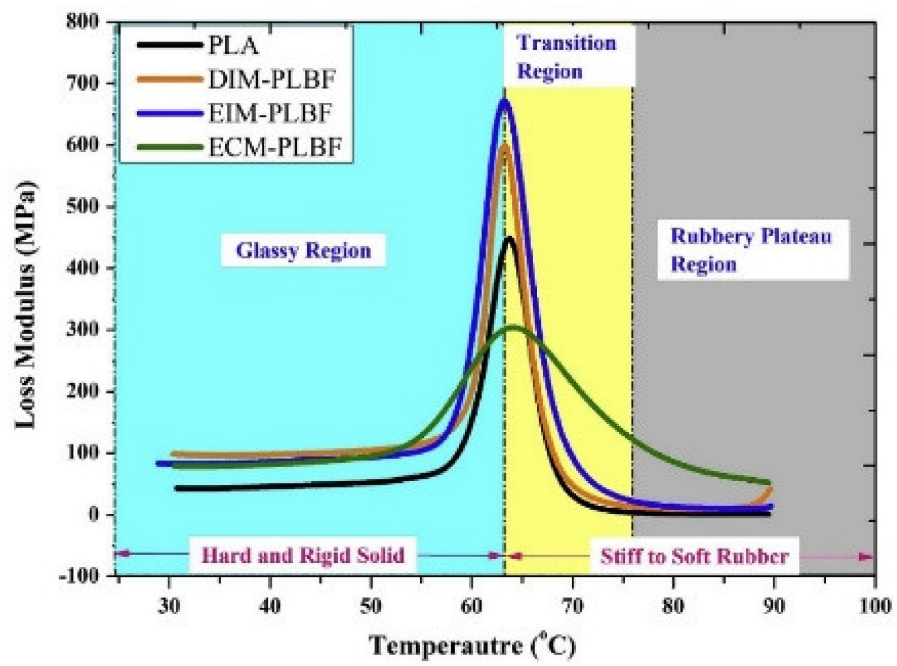

(b)

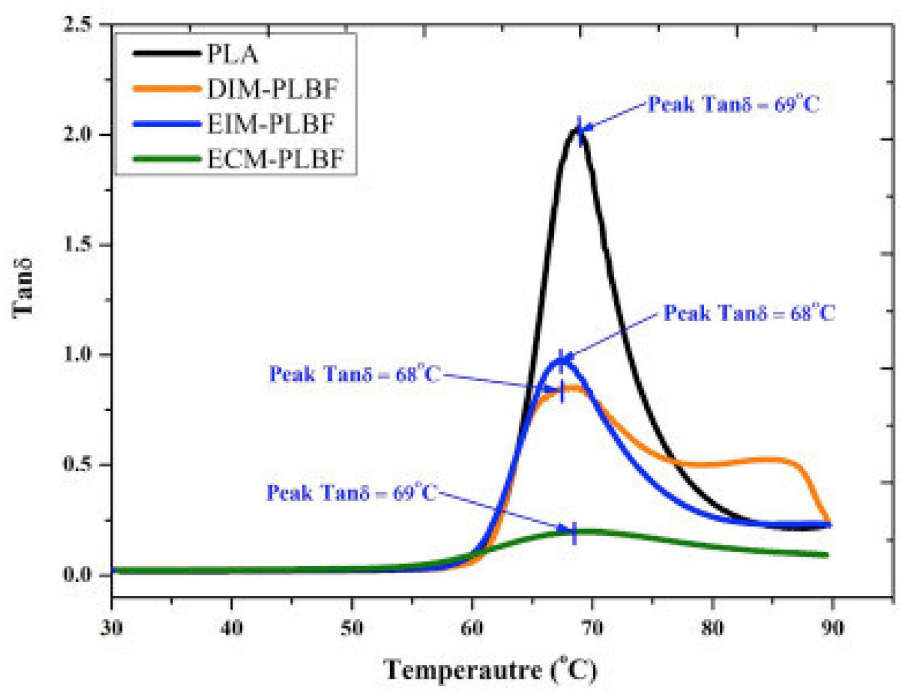

(c)

Figure 8. DMA test results of banana fiber/PLA composites (a) Storage modulus ( $\left.E^{\prime}\right)$ and (b) Loss modulus (E"), (c) Tan delta vs. temperature. Reproduced with permission from [156]. 
Table 5. Thermal properties of natural composites obtained from DMA analysis.

\begin{tabular}{|c|c|c|c|}
\hline Fiber & Matrix & Thermal Properties & Ref. \\
\hline \multicolumn{4}{|c|}{ Thermoset Matrices } \\
\hline Jute + sisal & Epoxy & $\begin{array}{l}\text { The hybridization increased the storage modulus }\left(E^{\prime}\right) \text { of composites. } T_{\mathrm{g}} \\
\text { of the hybrid composites was lower compared to pure jute composite. }\end{array}$ & [164] \\
\hline Kenaf & Polyurethane (PU) & $\begin{array}{l}\text { The acetylated treatment presented better values for storage } \\
\text { modulus }\left(E^{\prime}\right) \text { when compared with all other treatments. }\end{array}$ & [90] \\
\hline Pineapple + kenaf & Phenolic & The treated pineapple fiber increased the $T_{\mathrm{g}}$ of the composites. & [52] \\
\hline Mulberry & Polyester & $\begin{array}{l}10 \% \text { of } \mathrm{NaOH} \text { treatment increased the storage modulus }\left(E^{\prime}\right) \text { of the } \\
\text { composite. The fibers decreased the } T_{\mathrm{g}} \text { (values of } 69^{\circ} \mathrm{C} \text { was found } \\
\text { for the neat resin and } 63^{\circ} \mathrm{C} \text { was found for the untreated composites). }\end{array}$ & [82] \\
\hline Aloevera /Hemp/Flax & Epoxy & $\begin{array}{l}\text { The hybridization and chemical treatment }\left(\mathrm{BaSO}_{4}\right) \\
\text { increased the storage modulus }\left(E^{\prime}\right) \text { and } T_{g} \text { of composites. }\end{array}$ & [180] \\
\hline $\begin{array}{l}\text { Kenaf + Nanofiller } \\
\text { CNFs }\end{array}$ & Epoxy & $\begin{array}{l}\text { The incorporation of nanofiller improved the } T_{g} \\
\text { of the composites and improved thermal stability } \\
\text { and residual char of kenaf/epoxy composites. }\end{array}$ & [181] \\
\hline $\begin{array}{l}\text { Kenaf (KKK), } \\
\text { Sisal (SSS) and Kenaf + } \\
\text { Sisal (KSK and SKS) }\end{array}$ & Bio-Epoxy & $\begin{array}{l}\text { The incorporation of fibers (sisal and kenaf) did not affect the } T_{g} \\
\text { of the composites. The hybridization increased the values } \\
\text { of storage modulus }\left(E^{\prime}\right) \text { when compared to pure resin. }\end{array}$ & [166] \\
\hline Jute + Nanoclay & Epoxy & $\begin{array}{c}\text { The nanoclay modified jute composites presented higher } E^{\prime}, E^{\prime \prime} \\
\text { and } \tan \delta \text { values. The composites modified with } 5 \mathrm{wt} \% \text { of } \\
\text { nanoclay had improved viscoelastic properties. } 5 \% \text { treated } \\
\text { jute fiber composites presented the highest } E^{\prime} \text { and } E^{\prime \prime} \text { values } \\
\text { but the lowest } \tan \delta \text { value. } 5 \% \mathrm{NaOH}+5 \mathrm{wt} \% \text { nanoclay } \\
\text { specimens presented higher storage modulus and } T_{g} .\end{array}$ & [71] \\
\hline $\begin{array}{l}\text { Bamboo + Kenaf }+ \\
\quad \text { Nanoclay }\end{array}$ & Epoxy & $\begin{array}{l}\text { The addition of the nanofiller improved the storage modulus, loss } \\
\text { modulus and } \tan \delta \text { when compared to the other hybrid composite. }\end{array}$ & [182] \\
\hline Ramie + Buriti & Polyester & $\begin{array}{l}\text { The ramie reinforced composite treated with } 2 \% \text { de } \mathrm{NaOH} \\
\text { presented higher storage modulus and loss modulus } \\
\text { compared to the other treated cases. }\end{array}$ & {$[84]$} \\
\hline $\begin{array}{l}\text { Jute }+ \\
\text { Oil palm }\end{array}$ & Epoxy & $\begin{array}{l}\text { High oil palm to jute fiber ratio lowered the storage } \\
\text { modulus. Loss modulus presented an increasing } \\
\text { trend as a function of increasing jute fiber content. }\end{array}$ & [141] \\
\hline Bamboo + Kenaf & Epoxy & $\begin{array}{l}\text { The complex and storage modulus of bamboo composite are } \\
\text { higher compared to kenaf composite. Hybrid composites } \\
\text { value lie between bamboo and kenaf composites. }\end{array}$ & [179] \\
\hline Date palm + Bamboo & Epoxy & $\begin{array}{l}\text { The hybridization of the composite presents an increase of storage } \\
\text { modulus }\left(E^{\prime}\right) \text { when compared with single fiber composites. }\end{array}$ & [69] \\
\hline Buriti & Epoxy & $\begin{array}{l}\text { The addition of buriti fiber improved the storage } \\
\text { modulus }\left(E^{\prime}\right) \text { and } T_{g} \text { when compared with pure epoxy. }\end{array}$ & [183] \\
\hline \multicolumn{4}{|c|}{ Thermoplastic matrices } \\
\hline Flax + Basalt & PLA & $\begin{array}{l}\text { The addition of natural fiber increased the storage modulus }\left(E^{\prime}\right) \\
\text { of the composites when compared to pure PLA composite. }\end{array}$ & [151] \\
\hline Date palm & PVC and HDPE & $\begin{array}{l}\text { The chemical treatments increased the properties of } T_{g} \\
\text { and storage modulus }\left(E^{\prime}\right) \text { when compared to } \\
\text { untreated composites and pure matrix. }\end{array}$ & [70] \\
\hline Sisal & PLA & $\begin{array}{l}\text { The sisal fiber with } 15 \% \text { weight fraction increased the } \\
\text { thermal properties with maximum storage }\left(E^{\prime}=3430 \mathrm{MPa}\right) \\
\text { and maximum loss moduli }\left(E^{\prime \prime}=245 \mathrm{MPa}\right)\end{array}$ & [184] \\
\hline $\begin{array}{l}\text { Bamboo, wood } \\
\text { and coconut }\end{array}$ & PLA & $\begin{array}{l}\text { The addition of natural fibers increased the crystalline } \\
\text { degree of PLA matrix. Also, increased the storage } \\
\text { modulus }\left(E^{\prime}\right) \text { when compared with pure PLA. }\end{array}$ & [185] \\
\hline
\end{tabular}


Table 5. Cont.

\begin{tabular}{|c|c|c|c|}
\hline Fiber & Matrix & Thermal Properties & Ref. \\
\hline \multicolumn{4}{|c|}{ Thermoplastic matrices } \\
\hline $\begin{array}{l}\text { Bamboo, wood } \\
\text { and coconut }\end{array}$ & PLA & $\begin{array}{l}\text { The addition of natural fibers increased the crystalline } \\
\text { degree of PLA matrix. Also, increased the storage } \\
\text { modulus }\left(E^{\prime}\right) \text { when compared with pure PLA. }\end{array}$ & [185] \\
\hline $\begin{array}{l}\text { sugar palm fiber (SPF)- } \\
\text { and kenaf fiber (KF)- }\end{array}$ & Polypropylene (PP) & $\begin{array}{l}\text { The hybrid composite with the best ratio (PP/SPF/KF), T-SP5K5, } \\
\text { showed a loss modulus }\left(E^{\prime \prime}\right) \text { of } 86.2 \mathrm{MPa} \text { and a damping factor of } 0.058 \text {. }\end{array}$ & [61] \\
\hline Ramie & PLA & $\begin{array}{l}\text { The chemical treatments ( } \mathrm{NaOH} \text { and Silane) showed maximum } \\
\text { storage modulus }\left(E^{\prime}\right) \text { when compared to untreated composite. }\end{array}$ & [186] \\
\hline Coir + pineapple leaf & PLA & $\begin{array}{l}\text { The hybridization of the composite showed an increase of storage } \\
\text { modulus }\left(E^{\prime}\right) \text { and loss modulus }\left(E^{\prime \prime}\right) \text { when compared to pure PLA. }\end{array}$ & [187] \\
\hline Carpinus betulus L. & PP & $\begin{array}{l}\text { The incorporation of nanofiller increased the storage } \\
\text { modulus }\left(E^{\prime}\right) \text { and } T_{g} \text { when compared with pure PP. }\end{array}$ & [149] \\
\hline Kenaf & PLA & $\begin{array}{l}\text { The randomly oriented (ROFRPC) composite showed highest storage } \\
\text { modulus }\left(E^{\prime}\right) \text { when compared with unidirectional (UDFRPC) and } \\
\text { bidirectional (BDFRPC) kenaf composites. The incorporation of } \\
\text { different kenaf mats with PLA improved the } T_{g} \text { of the composites } \\
\text { as compared to neat PLA. ROFRPC showed the highest value of } T_{g} \text {. }\end{array}$ & [188] \\
\hline Basalt (BF) & PLA & $\begin{array}{l}\text { The addition of BF improved the storage modulus }\left(E^{\prime}\right) \\
\text { when compared with pure PLA. Increasing the fiber } \\
\text { content decreased } \tan \delta \text { (the presence of BF prevents } \\
\text { the chain mobility of the pure PLA). The addition of BF } \\
\text { had little influence on the } T_{g} \text { and } T_{m} \text { of the PLA composites. }\end{array}$ & [189] \\
\hline
\end{tabular}

\section{Conclusions}

Thermal analysis can provide useful information for the development of new materials and optimization of the selection process of these materials for new applications. The most common thermal properties studied in the literature are: the percentage of weight loss, the degradation temperature, $T_{g}$, and viscoelastic properties (storage modulus, loss modulus, and the damping factor). Different factors affect the thermal properties of natural fiber composites (i.e., fiber and matrix type, the presence of fillers, fiber content, and fiber orientation, the chemical treatment of the fibers, manufacturing process, and type of loading). It is crucial to ensure that the natural fibers used in the composites can withstand the heat required during the fabrication process and retain their characteristics after exposure to heat. Different approaches were used in the literature for the enhancement of thermal properties of natural fiber-based composite materials. For example, using natural fibers with low lignin content leads to a better thermal performance of composites. Another approach involves the removal of lignin through fiber treatment. Finally, the incorporation of synthetic fillers or synthetic fibers in natural fiber reinforced composites increase their thermal stability.

Author Contributions: Conceptualization, writing—original draft preparation, J.S.S.N. and M.D.B.; methodology, J.S.S.N. and H.F.M.d.Q.; supervision, M.D.B.; validation, R.A.A.A. and M.D.B.; writing-review \& editing, M.D.B. All authors have read and agreed to the published version of the manuscript.

Funding: This research was partially funded by the Brazilian Research Agencies: National Council for Scientific and Technological Development (CNPq)-Grant number 311079/2020-2, Coordenação de Aperfeiçoamento de Pessoal de Nível Superior-Brasil (CAPES)- Finance Code 001, and Fundação de Amparo à Pesquisa do Estado do Rio de Janeiro (FAPERJ)- Grant number E-26/211.072/2019 and E-26/202.728/2019.

Institutional Review Board Statement: Not applicable. 
Informed Consent Statement: Not applicable.

Acknowledgments: Brazilian Research Agencies: National Council for Scientific and Technological Development (CNPq), Coordenação de Aperfeiçoamento de Pessoal de Nível Superior-Brasil (CAPES) and Fundação de Amparo à Pesquisa do Estado do Rio de Janeiro (FAPERJ).

Conflicts of Interest: The authors declare that they have no conflict of interest to report regarding the present study.

\section{References}

1. Guo, R.; Xian, G.; Li, C.; Huang, X.; Xin, M. Effect of fiber hybridization types on the mechanical properties of carbon/glass fiber reinforced polymer composite rod. Mech. Adv. Mater. Struct. 2021, 1-13. [CrossRef]

2. Li, C.; Xian, G.; Li, H. Tension-tension fatigue performance of a large-diameter pultruded carbon/glass hybrid rod. Int. J. Fatigue 2019, 120, 141-149. [CrossRef]

3. Lal, H.M.; Uthaman, A.; Li, C.; Xian, G.; Thomas, S. Combined effects of cyclic/sustained bending loading and water immersion on the interface shear strength of carbon/glass fiber reinforced polymer hybrid rods for bridge cable. Constr. Build. Mater. 2022, 314, 125587. [CrossRef]

4. Budhe, S.; de Barros, S.; Banea, M.D. Theoretical assessment of the elastic modulus of natural fiber-based intra-ply hybrid composites. J. Braz. Soc. Mech. Sci. Eng. 2019, 41, 263. [CrossRef]

5. $\quad$ Banea, M.D.; Neto, J.S.S.; Cavalcanti, D.K.K. Recent Trends in Surface Modification of Natural Fibres for Their Use in Green Composites. In Green Composites; Thomas, S., Balakrishnan, P., Eds.; Springer: Singapore, 2021; pp. 329-350.

6. Wambua, P.; Ivens, J.; Verpoest, I. Natural fibres: Can they replace glass in fibre reinforced plastics? Compos. Sci. Technol. 2003, 63, 1259-1264. [CrossRef]

7. De Queiroz, H.F.M.; Banea, M.D.; Cavalcanti, D.K.K. Adhesively bonded joints of jute, glass and hybrid jute/glass fibre-reinforced polymer composites for automotive industry. Appl. Adhes. Sci. 2021, 9, 2. [CrossRef]

8. De Queiroz, H.F.M.; Banea, M.D.; Cavalcanti, D.K.K. Experimental analysis of adhesively bonded joints in synthetic- and natural fibre-reinforced polymer composites. J. Compos. Mater. 2020, 54, 1245-1255. [CrossRef]

9. De Queiroz, H.F.M.; Banea, M.D.; Cavalcanti, D.K.K.; de Souza e Silva Neto, J. The effect of multiscale hybridization on the mechanical properties of natural fiber-reinforced composites. J. Appl. Polym. Sci. 2021, 138, 51213. [CrossRef]

10. Pickering, K.L.; Efendy, M.A.; Le, T.M. A review of recent developments in natural fibre composites and their mechanical performance. Compos. Part A Appl. Sci. Manuf. 2016, 83, 98-112. [CrossRef]

11. Marichelvam, M.K.; Manimaran, P.; Verma, A.; Sanjay, M.R.; Siengchin, S.; Kandakodeeswaran, K.; Geetha, M. A novel palm sheath and sugarcane bagasse fiber based hybrid composites for automotive applications: An experimental approach. Polym. Compos. 2021, 42, 512-521. [CrossRef]

12. Akampumuza, O.; Wambua, P.M.; Ahmed, A.; Li, W.; Qin, X.-H. Review of the applications of biocomposites in the automotive industry. Polym. Compos. 2017, 38, 2553-2569. [CrossRef]

13. Fitzgerald, A.; Proud, W.; Kandemir, A.; Murphy, R.J.; Jesson, D.A.; Trask, R.S.; Hamerton, I.; Longana, M.L. A Life Cycle Engineering Perspective on Biocomposites as a Solution for a Sustainable Recovery. Sustainability 2021, 13, 1160. [CrossRef]

14. Islam, M.S.; Ahmed, S.J.U. Influence of jute fiber on concrete properties. Constr. Build. Mater. 2018, 189, 768-776. [CrossRef]

15. Benzait, Z.; Trabzon, L. A review of recent research on materials used in polymer-matrix composites for body armor application. J. Compos. Mater. 2018, 52, 3241-3263. [CrossRef]

16. Braga, F.D.O.; Bolzan, L.T.; da Luz, F.S.; Lopes, P.H.L.M.; Lima, É.P., Jr.; Monteiro, S.N. High energy ballistic and fracture comparison between multilayered armor systems using non-woven curaua fabric composites and aramid laminates. J. Mater. Res. Technol. 2017, 6, 417-422. [CrossRef]

17. Sanjay, M.; Siengchin, S.; Parameswaranpillai, J.; Jawaid, M.; Pruncu, C.I.; Khan, A. A comprehensive review of techniques for natural fibers as reinforcement in composites: Preparation, processing and characterization. Carbohydr. Polym. 2019, 207, 108-121.

18. Silva, R.V.; Aquino, E.M.F. Curaua Fiber: A New Alternative to Polymeric Composites. J. Reinf. Plast. Compos. 2008, $27,103-112$. [CrossRef]

19. Cavalcanti, D.K.K.; Banea, M.D.; Neto, J.S.S.; Lima, R.A.A. Comparative analysis of the mechanical and thermal properties of polyester and epoxy natural fibre-reinforced hybrid composites. J. Compos. Mater. 2021, 55, 1683-1692. [CrossRef]

20. Chaudhary, V.; Bajpai, P.K.; Maheshwari, S. Effect of moisture absorption on the mechanical performance of natural fiber reinforced woven hybrid bio-composites. J. Nat. Fibers 2020, 17, 84-100. [CrossRef]

21. Maslinda, A.B.; Abdul Majid, M.S.; Ridzuan, M.J.M.; Afendi, M.; Gibson, A.G. Effect of water absorption on the mechanical properties of hybrid interwoven cellulosic-cellulosic fibre reinforced epoxy composites. Compos. Struct. 2017, 167, 227-237. [CrossRef]

22. Choudhury, M.R.; Debnath, K. Green Composites: Introductory Overview. In Green Composites; Thomas, S., Balakrishnan, P., Eds.; Springer: Singapore, 2021; pp. 1-20.

23. El Messiry, M. Green Composite as an Adequate Material for Automotive Applications. In Green Composites; Thomas, S., Balakrishnan, P., Eds.; Springer: Singapore, 2021; pp. 151-208. 
24. Mahmud, S.; Hasan, K.M.F.; Jahid, M.A.; Mohiuddin, K.; Zhang, R.; Zhu, J. Comprehensive review on plant fiber-reinforced polymeric biocomposites. J. Mater. Sci. 2021, 56, 7231-7264. [CrossRef]

25. Do Nascimento, H.M.; dos Santos, A.; Duarte, V.A.; Bittencourt, P.R.S.; Radovanovic, E.; Fávaro, S.L. Characterization of natural cellulosic fibers from Yucca aloifolia L. leaf as potential reinforcement of polymer composites. Cellulose 2021, 28, 5477-5492. [CrossRef]

26. Gurunathan, T.; Mohanty, S.; Nayak, S.K. A review of the recent developments in biocomposites based on natural fibres and their application perspectives. Compos. Part A Appl. Sci. Manuf. 2015, 77, 1-25. [CrossRef]

27. Mehdikhani, M.; Gorbatikh, L.; Verpoest, I.; Lomov, S.V. Voids in fiber-reinforced polymer composites: A review on their formation, characteristics, and effects on mechanical performance. J. Compos. Mater. 2018, 53, 1579-1669. [CrossRef]

28. Sanjay, M.R.; Madhu, P.; Jawaid, M.; Senthamaraikannan, P.; Senthil, S.; Pradeep, S. Characterization and properties of natural fiber polymer composites: A comprehensive review. J. Clean. Prod. 2018, 172, 566-581. [CrossRef]

29. Siakeng, R.; Jawaid, M.; Ariffin, H.; Sapuan, S.M.; Asim, M.; Saba, N. Natural fiber reinforced polylactic acid composites: A review. Polym. Compos. 2019, 40, 446-463. [CrossRef]

30. Thyavihalli Girijappa, Y.G.; Mavinkere Rangappa, S.; Parameswaranpillai, J.; Siengchin, S. Natural Fibers as Sustainable and Renewable Resource for Development of Eco-Friendly Composites: A Comprehensive Review. Front. Mater. 2019, 6, 226. [CrossRef]

31. Sivaranjana, P.; Arumugaprabu, V. A brief review on mechanical and thermal properties of banana fiber based hybrid composites. SN Appl. Sci. 2021, 3, 176. [CrossRef]

32. Swolfs, Y.; Gorbatikh, L.; Verpoest, I. Fibre hybridisation in polymer composites: A review. Compos. Part A Appl. Sci. Manuf. 2014, 67, 181-200. [CrossRef]

33. Mahmoud Zaghloul, M.Y.; Yousry Zaghloul, M.M.; Yousry Zaghloul, M.M. Developments in polyester composite materialsAn in-depth review on natural fibres and nano fillers. Compos. Struct. 2021, 278, 114698. [CrossRef]

34. Odesanya, K.O.; Ahmad, R.; Jawaid, M.; Bingol, S.; Adebayo, G.O.; Wong, Y.H. Natural Fibre-Reinforced Composite for Ballistic Applications: A Review. J. Polym. Environ. 2021, 29, 3795-3812. [CrossRef]

35. Neto, J.; Queiroz, H.; Aguiar, R.; Lima, R.; Cavalcanti, D.; Banea, M.-D. A Review of Recent Advances in Hybrid Natural Fiber Reinforced Polymer Composites. J. Renew. Mater. 2022, 10, 561-589. [CrossRef]

36. Joseph, S.; Sreekala, M.S.; Thomas, S. Effect of chemical modifications on the thermal stability and degradation of banana fiber and banana fiber-reinforced phenol formaldehyde composites. J. Appl. Polym. Sci. 2008, 110, 2305-2314. [CrossRef]

37. Azwa, Z.N.; Yousif, B.F.; Manalo, A.C.; Karunasena, W. A review on the degradability of polymeric composites based on natural fibres. Mater. Des. 2013, 47, 424-442. [CrossRef]

38. Joseph, P.V.; Joseph, K.; Thomas, S.; Pillai, C.K.S.; Prasad, V.S.; Groeninckx, G.; Sarkissova, M. The thermal and crystallisation studies of short sisal fibre reinforced polypropylene composites. Compos. Part A Appl. Sci. Manuf. 2003, 34, 253-266. [CrossRef]

39. Asim, M.; Paridah, M.T.; Chandrasekar, M.; Shahroze, R.M.; Jawaid, M.; Nasir, M.; Siakeng, R. Thermal stability of natural fibers and their polymer composites. Iran. Polym. J. 2020, 29, 625-648. [CrossRef]

40. Fan, M.; Naughton, A. Mechanisms of thermal decomposition of natural fibre composites. Compos. Part B Eng. 2016, 88, 1-10. [CrossRef]

41. Grigore, M.E. Methods of Recycling, Properties and Applications of Recycled Thermoplastic Polymers. Recycling 2017, 2, 24. [CrossRef]

42. Zhou, Y.; Fan, M.; Chen, L. Interface and bonding mechanisms of plant fibre composites: An overview. Compos. Part B Eng. 2016, 101, 31-45. [CrossRef]

43. Beg, M.D.H.; Pickering, K.L. Mechanical performance of Kraft fibre reinforced polypropylene composites: Influence of fibre length, fibre beating and hygrothermal ageing. Compos. Part A Appl. Sci. Manuf. 2008, 39, 1748-1755. [CrossRef]

44. Gholampour, A.; Ozbakkaloglu, T. A review of natural fiber composites: Properties, modification and processing techniques, characterization, applications. J. Mater. Sci. 2020, 55, 829-892. [CrossRef]

45. Latif, R.; Wakeel, S.; Khan, N.Z.; Siddiquee, A.N.; Lal Verma, S.; Khan, Z.A. Surface treatments of plant fibers and their effects on mechanical properties of fiber-reinforced composites: A review. J. Reinf. Plast. Compos. 2018, 38, 15-30. [CrossRef]

46. De Araujo Alves Lima, R.; Cavalcanti, D.K.; de Souza e Silva Neto, J.; da Costa, H.M.; Banea, M.D. Effect of surface treatments on interfacial properties of natural intralaminar hybrid composites. Polym. Compos. 2020, 41, 314-325. [CrossRef]

47. Rout, J.; Misra, M.; Tripathy, S.S.; Nayak, S.K.; Mohanty, A.K. The influence of fibre treatment on the performance of coir-polyester composites. Compos. Sci. Technol. 2001, 61, 1303-1310. [CrossRef]

48. El Boustani, M.; Lebrun, G.; Brouillette, F.; Belfkira, A. Effect of a solvent-free acetylation treatment on reinforcements permeability and tensile behaviour of flax/epoxy and flax/wood fibre/epoxy composites. Can. J. Chem. Eng. 2017, 95, 1082-1092. [CrossRef]

49. Safri, S.N.A.; Sultan, M.T.H.; Saba, N.; Jawaid, M. Effect of benzoyl treatment on flexural and compressive properties of sugar palm/glass fibres/epoxy hybrid composites. Polym. Test. 2018, 71, 362-369. [CrossRef]

50. Vinayagamoorthy, R. Influence of fiber surface modifications on the mechanical behavior of Vetiveria zizanioides reinforced polymer composites. J. Nat. Fibers 2019, 16, 163-174. [CrossRef]

51. Zafeiropoulos, N.E.; Williams, D.R.; Baillie, C.A.; Matthews, F.L. Engineering and characterisation of the interface in flax fibre/polypropylene composite materials. Part I. Development and investigation of surface treatments. Compos. Part A Appl. Sci. Manuf. 2002, 33, 1083-1093. [CrossRef] 
52. Asim, M.; Paridah, M.T.; Saba, N.; Jawaid, M.; Alothman, O.Y.; Nasir, M.; Almutairi, Z. Thermal, physical properties and flammability of silane treated kenaf/pineapple leaf fibres phenolic hybrid composites. Compos. Struct. 2018, 202, 1330-1338. [CrossRef]

53. Rashid, B.; Leman, Z.; Jawaid, M.; Ghazali, M.J.; Ishak, M.R. Influence of Treatments on the Mechanical and Thermal Properties of Sugar Palm Fibre Reinforced Phenolic Composites. BioResources 2017, 12, 16.

54. Ouajai, S.; Shanks, R.A. Composition, structure and thermal degradation of hemp cellulose after chemical treatments. Polym. Degrad. Stab. 2005, 89, 327-335. [CrossRef]

55. Georgiopoulos, P.; Christopoulos, A.; Koutsoumpis, S.; Kontou, E. The effect of surface treatment on the performance of flax/biodegradable composites. Compos. Part B Eng. 2016, 106, 88-98. [CrossRef]

56. Kabir, M.M.; Wang, H.; Lau, K.T.; Cardona, F. Chemical treatments on plant-based natural fibre reinforced polymer composites: An overview. Compos. Part B Eng. 2012, 43, 2883-2892. [CrossRef]

57. Jandas, P.J.; Mohanty, S.; Nayak, S.K.; Srivastava, H. Effect of surface treatments of banana fiber on mechanical, thermal, and biodegradability properties of PLA/banana fiber biocomposites. Polym. Compos. 2011, 32, 1689-1700. [CrossRef]

58. Dixit, S.; Joshi, B.; Kumar, P.; Yadav, V.L. Novel Hybrid Structural Biocomposites from Alkali Treated-Date Palm and Coir Fibers: Morphology, Thermal and Mechanical Properties. J. Polym. Environ. 2020, 28, 2386-2392. [CrossRef]

59. Do Carmo, F.F.; do Nascimento, J.P.C.; de Morais, J.E.V.; Martins, V.C.; Sales, J.C.; Silva, M.A.S.; Silva, R.S.; Sombra, A.S.B. High thermal stability of the $\mathrm{YNbO}_{4}-\mathrm{CaYTiNbO}$ composites for radio frequency and microwave applications. Mater. Chem. Phys. 2021, 271, 124956. [CrossRef]

60. Ferreira, D.P.; Cruz, J.; Fangueiro, R. Surface modification of natural fibers in polymer composites. In Green Composites for Automotive Applications; Elsevier: Amsterdam, The Netherlands, 2019; pp. 3-41.

61. Izwan, S.M.; Sapuan, S.M.; Zuhri, M.Y.M.; Mohamed, A.R. Thermal stability and dynamic mechanical analysis of benzoylation treated sugar palm/kenaf fiber reinforced polypropylene hybrid composites. Polymers 2021, 13, 2961. [CrossRef]

62. Kumar, S.; Saha, A.; Bhowmik, S. Accelerated weathering effects on mechanical, thermal and viscoelastic properties of kenaf/ pineapple biocomposite laminates for load bearing structural applications. J. Appl. Polym. Sci. 2021, 139, 51465. [CrossRef]

63. Siakeng, R.; Jawaid, M.; Asim, M.; Saba, N.; Sanjay, M.; Siengchin, S.; Fouad, H. Alkali treated coir/pineapple leaf fibres reinforced PLA hybrid composites: Evaluation of mechanical, morphological, thermal and physical properties. Express Polym. Lett. 2020, 14, 717-730. [CrossRef]

64. Wang, F.; Zhou, S.; Li, L.; Zhang, X. Changes in the morphological-mechanical properties and thermal stability of bamboo fibers during the processing of alkaline treatment. Polym. Compos. 2018, 39, E1421-E1428. [CrossRef]

65. Neto, J.; Lima, R.; Cavalcanti, D.; Souza, J.; Aguiar, R.; Banea, M. Effect of chemical treatment on the thermal properties of hybrid natural fiber-reinforced composites. J. Appl. Polym. Sci. 2019, 136, 47154. [CrossRef]

66. Liu, K.; Zhang, X.; Takagi, H.; Yang, Z.; Wang, D. Effect of chemical treatments on transverse thermal conductivity of unidirectional abaca fiber/epoxy composite. Compos. Part A Appl. Sci. Manuf. 2014, 66, 227-236. [CrossRef]

67. Liew, F.K.; Hamdan, S.; Rahman, M.R.; Rusop, M.; Khan, A. Thermo-mechanical properties of jute/bamboo/polyethylene hybrid composites: The combined effects of silane coupling agent and copolymer. Polym. Compos. 2020, 41, 4830-4841. [CrossRef]

68. Asim, M.; Jawaid, M.; Fouad, H.; Alothman, O.Y. Effect of surface modified date palm fibre loading on mechanical, thermal properties of date palm reinforced phenolic composites. Compos. Struct. 2021, 267, 113913. [CrossRef]

69. Jawaid, M.; Awad, S.; Fouad, H.; Asim, M.; Saba, N.; Dhakal, H.N. Improvements in the thermal behaviour of date palm/bamboo fibres reinforced epoxy hybrid composites. Compos. Struct. 2021, 277, 114644. [CrossRef]

70. Maou, S.; Meghezzi, A.; Grohens, Y.; Meftah, Y.; Kervoelen, A.; Magueresse, A. Effect of various chemical modifications of date palm fibers (DPFs) on the thermo-physical properties of polyvinyl chloride (PVC)-high-density polyethylene (HDPE) composites. Ind. Crop. Prod. 2021, 171, 113974. [CrossRef]

71. Ramakrishnan, S.; Krishnamurthy, K.; Rajeshkumar, G.; Asim, M. Dynamic Mechanical Properties and Free Vibration Characteristics of Surface Modified Jute Fiber/Nano-Clay Reinforced Epoxy Composites. J. Polym. Environ. 2020, 29, 1076-1088. [CrossRef]

72. Premalatha, N.; Saravanakumar, S.S.; Sanjay, M.R.; Siengchin, S.; Khan, A. Structural and Thermal Properties of Chemically Modified Luffa Cylindrica Fibers. J. Nat. Fibers 2021, 18, 1038-1044. [CrossRef]

73. Węgrzyn, M.; Rudnik, E.; Kamocka-Bronisz, R.; Kukfisz, B. Mechanical and Thermal Properties of Biocomposites Based on Polyethylene from Renewable Resources Modified with Ionic Liquids. J. Polym. Environ. 2021, 29, 1808-1816. [CrossRef]

74. Hu, G.; Cai, S.Y.; Zhou, Y.H.; Zhang, N.W.; Ren, J. Enhanced mechanical and thermal properties of poly (lactic acid)/bamboo fiber composites via surface modification. J. Reinf. Plast. Compos. 2018, 37, 841-852. [CrossRef]

75. Zhang, K.Q.; Lin, J.Y.; Hao, C.Y.; Hong, G.H.; Chen, Z.H.; Chen, Z.J.; Zhang, S.B.; Song, W. Effect of Nano-hydroxyapatite Modification of Bamboo Fiber on the Properties of Bamboo Fiber/Polylactic Acid Composites. BioResources 2019, 14, 1694-1707. [CrossRef]

76. Oza, S.; Ning, H.B.; Ferguson, I.; Lu, N. Effect of surface treatment on thermal stability of the hemp-PLA composites: Correlation of activation energy with thermal degradation. Compos. Part B Eng. 2014, 67, 227-232. [CrossRef]

77. Sheng, K.C.; Zhang, S.; Qian, S.P.; Lopez, C.A.F. High-toughness PLA/Bamboo cellulose nanowhiskers bionanocomposite, strengthened with silylated ultrafine bamboo-char. Compos. Part B Eng. 2019, 165, 174-182. [CrossRef] 
78. Masirek, R.; Kulinski, Z.; Chionna, D.; Piorkowska, E.; Pracella, M. Composites of poly(L-lactide) with hemp fibers: Morphology and thermal and mechanical properties. J. Appl. Polym. Sci. 2007, 105, 255-268. [CrossRef]

79. Bodur, M.S.; Bakkal, M.; Sonmez, H.E. The effects of different chemical treatment methods on the mechanical and thermal properties of textile fiber reinforced polymer composites. J. Compos. Mater. 2016, 50, 3817-3830. [CrossRef]

80. Fiore, V.; Scalici, T.; Valenza, A. Effect of sodium bicarbonate treatment on mechanical properties of flax-reinforced epoxy composite materials. J. Compos. Mater. 2018, 52, 1061-1072. [CrossRef]

81. Shanmugasundaram, N.; Rajendran, I.; Ramkumar, T. Static, dynamic mechanical and thermal properties of untreated and alkali treated mulberry fiber reinforced polyester composites. Polym. Compos. 2018, 39, E1908-E1919. [CrossRef]

82. Gupta, M. Investigations on jute fibre-reinforced polyester composites: Effect of alkali treatment and poly (lactic acid) coating. J. Ind. Text. 2020, 49, 923-942. [CrossRef]

83. Lavoratti, A.; Romanzini, D.; Amico, S.C.; Zattera, A.J. Influence of Fibre Treatment on the Characteristics of Buriti and Ramie Polyester Composites. Polym. Polym. Compos. 2017, 25, 247-256. [CrossRef]

84. Chin, S.C.; Tee, K.F.; Tong, F.S.; Ong, H.R.; Gimbun, J. Thermal and mechanical properties of bamboo fiber reinforced composites. Mater. Today Commun. 2020, 23, 100876. [CrossRef]

85. Teixeira, L.A.; Junior, L.V.D.; Luz, S.M. Chemical treatment of curaua fibres and its effect on the mechanical performance of fibre/polyester composites. Plast. Rubber Compos. 2020, 50, 189-199. [CrossRef]

86. Chung, T.-J.; Park, J.-W.; Lee, H.-J.; Kwon, H.-J.; Kim, H.-J.; Lee, Y.-K.; Tze, W.T.Y. The improvement of mechanical properties, thermal stability, and water absorption resistance of an eco-friendly PLA/kenaf biocomposite using acetylation. Appl. Sci. 2018, 8, 376. [CrossRef]

87. Zaman, H.U.; Khan, R.A. Acetylation used for natural fiber/polymer composites. J. Thermoplast. Compos. Mater. 2019, 34, 3-23. [CrossRef]

88. Goriparthi, B.K.; Suman, K.N.S.; Mohan Rao, N. Effect of fiber surface treatments on mechanical and abrasive wear performance of polylactide/jute composites. Compos. Part A Appl. Sci. Manuf. 2012, 43, 1800-1808. [CrossRef]

89. Datta, J.; Kopczyńska, P. Effect of kenaf fibre modification on morphology and mechanical properties of thermoplastic polyurethane materials. Ind. Crop. Prod. 2015, 74, 566-576. [CrossRef]

90. Asaithambi, B.; Ganesan, G.S.; Kumar, S.A. Banana/sisal fibers reinforced poly (lactic acid) hybrid biocomposites; influence of chemical modification of BSF towards thermal properties. Polym. Compos. 2017, 38, 1053-1062. [CrossRef]

91. Jabbar, A.; Militký, J.; Wiener, J.; Karahan, M. Static and dynamic mechanical properties of novel treated jute/green epoxy composites. Text. Res. J. 2016, 86, 960-974. [CrossRef]

92. Costa, I.L.M.; Pereira, P.H.F.; Claro, A.M.; Amaral, N.C.D.; Barud, H.D.S.; Ribeiro, R.B.; Mulinari, D.R. 3D-printing pen from valorization of pine cone residues as reinforcement in acrylonitrile butadiene styrene (ABS): Microstructure and thermal properties. J. Thermoplast. Compos. Mater. 2021, 1-20. [CrossRef]

93. Yu, T.; Jiang, N.; Li, Y. Study on short ramie fiber/poly(lactic acid) composites compatibilized by maleic anhydride. Compos. Part A Appl. Sci. Manuf. 2014, 64, 139-146. [CrossRef]

94. Yiga, V.A.; Lubwama, M.; Pagel, S.; Benz, J.; Olupot, P.W.; Bonten, C. Flame retardancy and thermal stability of agricultural residue fiber-reinforced polylactic acid: A Review. Polym. Compos. 2021, 42, 15-44. [CrossRef]

95. Nam, T.H.; Ogihara, S.; Kobayashi, S. Interfacial, mechanical and thermal properties of coir fiber-reinforced poly(lactic acid) biodegradable composites. Adv. Compos. Mater. 2012, 21, 103-122. [CrossRef]

96. Mukherjee, T.; Kao, N. PLA Based Biopolymer Reinforced with Natural Fibre: A Review. J. Polym. Environ. 2011, 19, 714-725. [CrossRef]

97. Rajeshkumar, G.; Arvindh Seshadri, S.; Devnani, G.L.; Sanjay, M.R.; Siengchin, S.; Prakash Maran, J.; Al-Dhabi, N.A.; Karuppiah, P.; Mariadhas, V.A.; Sivarajasekar, N.; et al. Environment friendly, renewable and sustainable poly lactic acid (PLA) based natural fiber reinforced composites-A comprehensive review. J. Clean. Prod. 2021, 310, 127483. [CrossRef]

98. Mallick, P.K. 5-Thermoplastics and thermoplastic-Matrix composites for lightweight automotive structures. In Materials, Design and Manufacturing for Lightweight Vehicles; Mallick, P.K., Ed.; Woodhead Publishing: Cambridge, UK, 2010; pp. $174-207$.

99. Chilali, A.; Assarar, M.; Zouari, W.; Kebir, H.; Ayad, R. Effect of geometric dimensions and fibre orientation on 3D moisture diffusion in flax fibre reinforced thermoplastic and thermosetting composites. Compos. Part A Appl. Sci. Manuf. 2017, 95, 75-86. [CrossRef]

100. Atiqah, A.; Jawaid, M.; Sapuan, S.; Ishak, M.; Alothman, O.Y. Thermal properties of sugar palm/glass fiber reinforced thermoplastic polyurethane hybrid composites. Compos. Struct. 2018, 202, 954-958. [CrossRef]

101. Enciso, B.; Abenojar, J.; Paz, E.; Martínez, M. Influence of low pressure plasma treatment on the durability of thermoplastic composites LDPE-flax/coconut under thermal and humidity conditions. Fibers Polym. 2018, 19, 1327-1334. [CrossRef]

102. Atiqah, A.; Jawaid, M.; Sapuan, S.; Ishak, M. Dynamic mechanical properties of sugar palm/glass fiber reinforced thermoplastic polyurethane hybrid composites. Polym. Compos. 2019, 40, 1329-1334. [CrossRef]

103. Radzi, A.M.; Sapuan, S.M.; Jawaid, M.; Mansor, M.R. Water absorption, thickness swelling and thermal properties of roselle/sugar palm fibre reinforced thermoplastic polyurethane hybrid composites. J. Mater. Res. Technol. 2019, 8, 3988-3994. [CrossRef]

104. Nair, S.T.; Vijayan, P.P.; George, S.C.; Kalarikkal, N.; Thomas, S. Enhanced mechanical and thermal performance of multiwalled carbon nanotubes-filled polypropylene/natural rubber thermoplastic elastomers. New J. Chem. 2021, 45, 4963-4976. [CrossRef] 
105. Wong, J.F.; Chan, J.X.; Hassan, A.; Mohamad, Z.; Othman, N. Thermal and flammability properties of wollastonite-filled thermoplastic composites: A review. J. Mater. Sci. 2021, 56, 8911-8950. [CrossRef]

106. Pereira, A.L.; Banea, M.D.; Neto, J.S.; Cavalcanti, D.K. Mechanical and Thermal Characterization of Natural Intralaminar Hybrid Composites Based on Sisal. Polymers 2020, 12, 866. [CrossRef]

107. George, A.; Sanjay, M.R.; Srisuk, R.; Parameswaranpillai, J.; Siengchin, S. A comprehensive review on chemical properties and applications of biopolymers and their composites. Int. J. Biol. Macromol. 2020, 154, 329-338. [CrossRef] [PubMed]

108. Yorseng, K.; Rangappa, S.M.; Parameswaranpillai, J.; Siengchin, S. Influence of Accelerated Weathering on the Mechanical, Fracture Morphology, Thermal Stability, Contact Angle, and Water Absorption Properties of Natural Fiber Fabric-Based Epoxy Hybrid Composites. Polymers 2020, 12, 2254. [CrossRef]

109. Kusić, D.; Božič, U.; Monzón, M.; Paz, R.; Bordón, P. Thermal and Mechanical Characterization of Banana Fiber Reinforced Composites for Its Application in Injection Molding. Materials 2020, 13, 3581. [CrossRef]

110. Saba, N.; Jawaid, M.; Alothman, O.Y.; Paridah, M. A review on dynamic mechanical properties of natural fibre reinforced polymer composites. Constr. Build. Mater. 2016, 106, 149-159. [CrossRef]

111. Ashok, R.; Srinivasa, C.; Basavaraju, B. Dynamic mechanical properties of natural fiber composites-A review. Adv. Compos. Hybrid Mater. 2019, 2, 586-607. [CrossRef]

112. Biswas, B.; Chabri, S.; Sawai, P.; Mitra, B.C.; Das, K.; Sinha, A. Effect of copper incorporation on the mechanical and thermal behavior of jute fiber reinforced unsaturated polyester composites. Polym. Compos. 2018, 39, E1315-E1330. [CrossRef]

113. Ramesh, P.; Prasad, B.D.; Narayana, K.L. Influence of Montmorillonite Clay Content on Thermal, Mechanical, Water Absorption and Biodegradability Properties of Treated Kenaf Fiber/PLA-Hybrid Biocomposites. Silicon 2021, 13, 109-118. [CrossRef]

114. Soatthiyanon, N.; Aumnate, C.; Srikulkit, K. Rheological, tensile, and thermal properties of poly(butylene succinate) composites filled with two types of cellulose (kenaf cellulose fiber and commercial cellulose). Polym. Compos. 2020, 41, 2777-2791. [CrossRef]

115. Sumesh, K.R.; Kanthavel, K.; Kavimani, V. Peanut oil cake-derived cellulose fiber: Extraction, application of mechanical and thermal properties in pineapple/flax natural fiber composites. Int. J. Biol. Macromol. 2020, 150, 775-785. [CrossRef]

116. Babu, N.B.K.; Muthukumaran, S.; Ramesh, T.; Arokiasamy, S. Effect of Agro-waste Microcoir Pith and Nano-alumina Reinforcement on Thermal Degradation and Dynamic Mechanical Behavior of Polyester Composites. J. Nat. Fibers 2021, 18, 581-593. [CrossRef]

117. Ojha, A.R.; Biswal, S.K. Thermo physico-mechanical behavior of palm stalk fiber reinforced epoxy composites filled with granite powder. Compos. Commun. 2019, 16, 158-161. [CrossRef]

118. Prasob, P.A.; Sasikumar, M. Static and dynamic behavior of jute/epoxy composites with $\mathrm{ZnO}$ and $\mathrm{TiO}_{2}$ fillers at different temperature conditions. Polym. Test. 2018, 69, 52-62. [CrossRef]

119. Ramakrishnan, S.; Krishnamurthy, K.; Rajasekar, R.; Rajeshkumar, G. An experimental study on the effect of nano-clay addition on mechanical and water absorption behaviour of jute fibre reinforced epoxy composites. J. Ind. Text. 2019, 49, 597-620. [CrossRef]

120. Reddy, K.M.; Vardhan, D.H.; Reddy, Y.S.K.; Raghavendra, G.; Rudrapati, R. Experimental Study of Thermal and Mechanical Behaviour of Graphite-Filled UJF Composite. Adv. Mater. Sci. Eng. 2021, 2021, 3739573. [CrossRef]

121. Sajith, T.A.; Praveen, K.M.; Thomas, S.; Ahmad, Z.; Kalarikkal, N.; Dhanani, C.; Maria, H.J. Effect of HAF carbon black on curing, mechanical, thermal and neutron shielding properties of natural rubber-Low-density polyethylene composites. Prog. Nucl. Energy 2021, 141, 103940. [CrossRef]

122. Sumesh, K.R.; Kanthavel, K. Effect of $\mathrm{TiO}_{2}$ nano-filler in mechanical and free vibration damping behavior of hybrid natural fiber composites. J. Braz. Soc. Mech. Sci. Eng. 2020, 42, 211. [CrossRef]

123. Sumesh, K.R.; Kanthavel, K.; Ajithram, A.; Nandhini, P. Bioalumina Nano Powder Extraction and its Applications for Sisal, Coir and Banana Hybrid Fiber Composites: Mechanical and Thermal Properties. J. Polym. Environ. 2019, 27, 2068-2077. [CrossRef]

124. Vivek, S.; Kanthavel, K. Effect of bagasse ash filled epoxy composites reinforced with hybrid plant fibres for mechanical and thermal properties. Compos. Part B Eng. 2019, 160, 170-176. [CrossRef]

125. Wu, H.; Xu, D.; Zhou, Y.; Guo, J.; He, W.; He, Y.; Yi, Y.; Qin, S. The Improved Mechanical and Thermal Properties of Hemp Fibers Reinforced Polypropylene Composites with Dodecyl Bromide Modification. Fibers Polym. 2021, 22, 2869-2877. [CrossRef]

126. Xu, S.; Sun, L.; He, J.; Han, H.; Wang, H.; Fang, Y.; Wang, Q. Effects of LiCl on crystallization, thermal, and mechanical properties of polyamide 6/wood fiber composites. Polym. Compos. 2018, 39, E1574-E1580. [CrossRef]

127. Arulmurugan, M.; Selvakumar, A.S.; Prabu, K.; Rajamurugan, G. Effect of barium sulphate on mechanical, DMA and thermal behaviour of woven aloevera/flax hybrid composites. Bull. Mater. Sci. 2020, 43, 58. [CrossRef]

128. Neto, J.S.S.; Banea, M.D.; Cavalcanti, D.K.K.; Queiroz, H.F.M.; Aguiar, R.A.A. Analysis of mechanical and thermal properties of epoxy multiwalled carbon nanocomposites. J. Compos. Mater. 2020, 54, 4831-4840. [CrossRef]

129. Mohit, H.; Srisuk, R.; Sanjay, M.R.; Siengchin, S.; Khan, A.; Marwani, H.M.; Dzudzevic-Cancar, H.; Asiri, A.M. Nanoparticles Addition in Coir-Basalt-Innegra Fibers Reinforced Bio-synthetic Epoxy Composites. J. Polym. Environ. 2021, 29, $3561-3573$. [CrossRef]

130. Mohit, H.; Sanjay, M.R.; Siengchin, S.; Khan, A.; Marwani, H.M.; Dzudzevic-Cancar, H.; Asiri, A.M. Effect of TiC Nanoparticles Reinforcement in Coir Fiber Based Bio/Synthetic Epoxy Hybrid Composites: Mechanical and Thermal Characteristics. J. Polym. Environ. 2021, 29, 2609-2627. [CrossRef]

131. Neves, R.M.; Zattera, A.J.; Amico, S.C. Enhancing thermal and dynamic-mechanical properties of epoxy reinforced by aminofunctionalized microcrystalline cellulose. J. Appl. Polym. Sci. 2021, 138, 51329. [CrossRef] 
132. Barbosa, A.Q.; Da Silva, L.F.M.; Banea, M.D.; Öchsner, A. Methods to increase the toughness of structural adhesives with micro particles: An overview with focus on cork particles. Mater. Werkst. 2016, 47, 307-325. [CrossRef]

133. Bhoopathi, R.; Ramesh, M. Influence of eggshell nanoparticles and effect of alkalization on characterization of industrial hemp fibre reinforced epoxy composites. J. Polym. Environ. 2020, 28, 2178-2190. [CrossRef]

134. Gouda, K.; Bhowmik, S.; Das, B. Synergetic Effect of Micro-bamboo Filler and Graphene Nanoplatelets on Thermomechanical Properties of Epoxy-Based Hybrid Composite. JOM 2020, 72, 4466-4476. [CrossRef]

135. Souza, A.T.; Junio, R.F.P.; Neuba, L.D.M.; Candido, V.S.; da Silva, A.C.R.; de Azevedo, A.R.G.; Monteiro, S.N.; Nascimento, L.F.C. Caranan Fiber from Mauritiella armata Palm Tree as Novel Reinforcement for Epoxy Composites. Polymers 2020, $12,2037$. [CrossRef]

136. Devireddy, S.B.R.; Biswas, S. Physical and thermal properties of unidirectional banana-jute hybrid fiber-reinforced epoxy composites. J. Reinf. Plast. Compos. 2016, 35, 1157-1172. [CrossRef]

137. Asim, M.; Jawaid, M.; Paridah, M.T.; Saba, N.; Nasir, M.; Shahroze, R.M. Dynamic and thermo-mechanical properties of hybridized kenaf/PALF reinforced phenolic composites. Polym. Compos. 2019, 40, 3814-3822. [CrossRef]

138. Krishnasamy, S.; Thiagamani, S.M.K.; Kumar, C.M.; Nagarajan, R.; Shahroze, R.; Siengchin, S.; Ismail, S.O.; M.P, I.D. Recent advances in thermal properties of hybrid cellulosic fiber reinforced polymer composites. Int. J. Biol. Macromol. 2019, 141, 1-13. [CrossRef]

139. Monteiro, S.N.; Calado, V.; Rodriguez, R.J.S.; Margem, F.M. Thermogravimetric behavior of natural fibers reinforced polymer composites-An overview. Mater. Sci. Eng. A 2012, 557, 17-28. [CrossRef]

140. Guo, Y.; Zhu, S.; Chen, Y.; Li, D. Thermal properties of wood-plastic composites with different compositions. Materials 2019, 12, 881. [CrossRef]

141. Jawaid, M.; Khalil, H.A.; Bakar, A.A.; Hassan, A.; Dungani, R. Effect of jute fibre loading on the mechanical and thermal properties of oil palm-epoxy composites. J. Compos. Mater. 2013, 47, 1633-1641. [CrossRef]

142. Junior, V.D.L.; Leão, R.M.; Steier, V.F.; da Luz, S.M. Influence of cure agent, treatment and fibre content on the thermal behaviour of a curaua/epoxy prepreg. Plast. Rubber Compos. 2020, 49, 214-221. [CrossRef]

143. Li, C.; Yin, X.; Wang, Y.; Zhang, L.; Zhang, Z.; Liu, Y.; Xian, G. Mechanical property evolution and service life prediction of pultruded carbon/glass hybrid rod exposed in harsh oil-well condition. Compos. Struct. 2020, 246, 112418. [CrossRef]

144. Bessa, W.; Trache, D.; Derradji, M.; Ambar, H.; Benziane, M.; Guedouar, B. Effect of different chemical treatments and loadings of Arundo donax L. fibers on the dynamic mechanical, thermal, and morphological properties of bisphenol A aniline based polybenzoxazine composites. Polym. Compos. 2021, 42, 5199-5208. [CrossRef]

145. Hidalgo-Salazar, M.A.; Correa, J.P. Mechanical and thermal properties of biocomposites from nonwoven industrial Fique fiber mats with Epoxy Resin and Linear Low Density Polyethylene. Results Phys. 2018, 8, 461-467. [CrossRef]

146. Dong, Y.; Ghataura, A.; Takagi, H.; Haroosh, H.J.; Nakagaito, A.N.; Lau, K.-T. Polylactic acid (PLA) biocomposites reinforced with coir fibres: Evaluation of mechanical performance and multifunctional properties. Compos. Part A Appl. Sci. Manuf. 2014, 63, 76-84. [CrossRef]

147. Yussuf, A.A.; Massoumi, I.; Hassan, A. Comparison of Polylactic Acid/Kenaf and Polylactic Acid/Rise Husk Composites: The Influence of the Natural Fibers on the Mechanical, Thermal and Biodegradability Properties. J. Polym. Environ. 2010, 18, 422-429. [CrossRef]

148. Głowińska, E.; Datta, J.; Parcheta, P. Effect of sisal fiber filler on thermal properties of bio-based polyurethane composites. J. Therm. Anal. Calorim. 2017, 130, 113-122. [CrossRef]

149. Atagur, M.; Seki, Y.; Pasaoglu, Y.; Sever, K.; Seki, Y.; Sarikanat, M.; Altay, L. Mechanical and thermal properties of Carpinas betulus fiber filled polypropylene composites. Polym. Compos. 2020, 41, 1925-1935. [CrossRef]

150. Nimanpure, S.; Hashmi, S.A.R.; Kumar, R.; Bhargaw, H.N.; Kumar, R.; Nair, P.; Naik, A. Mechanical, electrical, and thermal analysis of sisal fibril/kenaf fiber hybrid polyester composites. Polym. Compos. 2019, 40, 664-676. [CrossRef]

151. Eselini, N.; Tirkes, S.; Akar, A.O.; Tayfun, U. Production and characterization of poly (lactic acid)-based biocomposites filled with basalt fiber and flax fiber hybrid. J. Elastomers Plast. 2020, 52, 701-716. [CrossRef]

152. Fang, C.-C.; Zhang, Y.; Qi, S.-Y.; Liao, Y.-C.; Li, Y.-Y.; Wang, P. Influence of structural design on mechanical and thermal properties of jute reinforced polylactic acid (PLA) laminated composites. Cellulose 2020, 27, 9397-9407. [CrossRef]

153. Boopalan, M.; Niranjanaa, M.; Umapathy, M.J. Study on the mechanical properties and thermal properties of jute and banana fiber reinforced epoxy hybrid composites. Compos. Part B Eng. 2013, 51, 54-57. [CrossRef]

154. De Rosa, I.M.; Santulli, C.; Sarasini, F. Mechanical and thermal characterization of epoxy composites reinforced with random and quasi-unidirectional untreated Phormium tenax leaf fibers. Mater. Des. 2010, 31, 2397-2405. [CrossRef]

155. Neher, B.; Bhuiyan, M.M.R.; Kabir, H.; Gafur, M.A.; Qadir, M.R.; Ahmed, F. Thermal properties of palm fiber and palm fiber-reinforced ABS composite. J. Therm. Anal. Calorim. 2016, 124, 1281-1289. [CrossRef]

156. Komal, U.K.; Lila, M.K.; Singh, I. PLA/banana fiber based sustainable biocomposites: A manufacturing perspective. Compos. Part B Eng. 2020, 180, 107535. [CrossRef]

157. Gheith, M.H.; Aziz, M.A.; Ghori, W.; Saba, N.; Asim, M.; Jawaid, M.; Alothman, O.Y. Flexural, thermal and dynamic mechanical properties of date palm fibres reinforced epoxy composites. J. Mater. Res. Technol. 2019, 8, 853-860. [CrossRef]

158. Kumar, A.A.J.; Prakash, M. Thermal properties of basalt/Cissus quadrangularis hybrid fiber reinforced polylactic acid biomedical composites. J. Therm. Anal. Calorim. 2020, 141, 717-725. [CrossRef] 
159. Wang, W.; Liu, L.; Ding, N.; Zhang, R.; Yu, J. Mechanical and thermal behavior analysis of wood-polypropylene composites. Text. Res. J. 2021, 91, 347-357. [CrossRef]

160. Margoto, O.H.; Prado, K.D.S.D.; Mergulhão, R.C.; Moris, V.A.D.S.; de Paiva, J.M.F. Mechanical and Thermal Characterization of Jute Fabric-Reinforced Polypropylene Composites: Effect of Maleic Anhydride. J. Nat. Fibers 2020, 1-13. [CrossRef]

161. Kamarudin, S.H.; Abdullah, L.C.; Aung, M.M.; Ratnam, C.T. Thermal and Structural Analysis of Epoxidized Jatropha Oil and Alkaline Treated Kenaf Fiber Reinforced Poly(Lactic Acid) Biocomposites. Polymers 2020, 12, 2604. [CrossRef] [PubMed]

162. Jesuarockiam, N.; Jawaid, M.; Zainudin, E.S.; Sultan, M.T.H.; Yahaya, R. Enhanced Thermal and Dynamic Mechanical Properties of Synthetic/Natural Hybrid Composites with Graphene Nanoplateletes. Polymers 2019, 11, 1085. [CrossRef]

163. Veerasimman, A.; Shanmugam, V.; Rajendran, S.; Johnson, D.J.; Subbiah, A.; Koilpichai, J.; Marimuthu, U. Thermal Properties of Natural Fiber Sisal Based Hybrid Composites-A Brief Review. J. Nat. Fibers 2021, 1-11. [CrossRef]

164. Gupta, M.K. Thermal and dynamic mechanical analysis of hybrid jute/sisal fibre reinforced epoxy composite. Proc. Inst. Mech. Eng. Part L J. Mater. Des. Appl. 2016, 232, 743-748. [CrossRef]

165. Biswas, B.; Sawai, P.; Santra, A.; Gain, A.; Saha, P.; Mitra, B.C.; Bandyopadhyay, N.R.; Sinha, A. Thermal stability, swelling and degradation behaviour of natural fibre based hybrid polymer composites. Cellulose 2019, 26, 4445-4461. [CrossRef]

166. Yorseng, K.; Rangappa, S.M.; Pulikkalparambil, H.; Siengchin, S.; Parameswaranpillai, J. Accelerated weathering studies of kenaf/sisal fiber fabric reinforced fully biobased hybrid bioepoxy composites for semi-structural applications: Morphology, thermo-mechanical, water absorption behavior and surface hydrophobicity. Constr. Build. Mater. 2020, 235, 117464. [CrossRef]

167. Saw, S.K.; Sarkhel, G.; Choudhury, A. Preparation and characterization of chemically modified Jute-Coir hybrid fiber reinforced epoxy novolac composites. J. Appl. Polym. Sci. 2012, 125, 3038-3049. [CrossRef]

168. Prasad, V.; Joseph, M.A.; Sekar, K. Investigation of mechanical, thermal and water absorption properties of flax fibre reinforced epoxy composite with nano $\mathrm{TiO}_{2}$ addition. Compos. Part A Appl. Sci. Manuf. 2018, 115, 360-370. [CrossRef]

169. Guo, J.; Cao, M.; Ren, W.; Wang, H.; Yu, Y. Mechanical, dynamic mechanical and thermal properties of $\mathrm{TiO}_{2}$ nanoparticles treatment bamboo fiber-reinforced polypropylene composites. J. Mater. Sci. 2021, 56, 12643-12659. [CrossRef]

170. Wang, F.; Zhou, S.; Yang, M.; Chen, Z.; Ran, S. Thermo-Mechanical Performance of Polylactide Composites Reinforced with Alkali-Treated Bamboo Fibers. Polymers 2018, 10, 401. [CrossRef] [PubMed]

171. Tawakkal, I.S.M.A.; Cran, M.J.; Bigger, S.W. Effect of kenaf fibre loading and thymol concentration on the mechanical and thermal properties of PLA/kenaf/thymol composites. Ind. Crop. Prod. 2014, 61, 74-83. [CrossRef]

172. Zhang, L.; Sun, Z.H.; Liang, D.P.; Lin, J.; Xiao, W. Preparation and Performance Evaluation of PLA/Coir Fibre Biocomposites. BioResources 2017, 12, 7349-7362. [CrossRef]

173. Chandrasekar, M.; Ishak, M.; Sapuan, S.; Leman, Z.; Jawaid, M. A review on the characterisation of natural fibres and their composites after alkali treatment and water absorption. Plast. Rubber Compos. 2017, 46, 119-136. [CrossRef]

174. Lu, N.; Oza, S. A comparative study of the mechanical properties of hemp fiber with virgin and recycled high density polyethylene matrix. Compos. Part B Eng. 2013, 45, 1651-1656. [CrossRef]

175. Jawaid, M.; Khalil, H.A.; Hassan, A.; Dungani, R.; Hadiyane, A. Effect of jute fibre loading on tensile and dynamic mechanical properties of oil palm epoxy composites. Compos. Part B Eng. 2013, 45, 619-624. [CrossRef]

176. Wang, Z.; Xian, G.; Zhao, X.-L. Effects of hydrothermal aging on carbon fibre/epoxy composites with different interfacial bonding strength. Constr. Build. Mater. 2018, 161, 634-648. [CrossRef]

177. Akay, M. Aspects of dynamic mechanical analysis in polymeric composites. Compos. Sci. Technol. 1993, 47, 419-423. [CrossRef]

178. Kumar, A.M.; Parameshwaran, R.; Rajasekar, R. Effect of abaca reinforced polymer composite on dynamic mechanical analysis. Colloid Polym. Sci. 2021, 299, 1657-1667. [CrossRef]

179. Chee, S.S.; Jawaid, M.; Sultan, M.T.H.; Alothman, O.Y.; Abdullah, L.C. Thermomechanical and dynamic mechanical properties of bamboo/woven kenaf mat reinforced epoxy hybrid composites. Compos. Part B Eng. 2019, 163, 165-174. [CrossRef]

180. Arulmurugan, M.; Prabu, K.; Rajamurugan, G.; Selvakumar, A.S. Viscoelastic behavior of aloevera/hemp/flax sandwich laminate composite reinforced with BaSO4: Dynamic mechanical analysis. J. Ind. Text. 2019, 50, 1040-1064. [CrossRef]

181. Khan, A.; Asiri, A.M.; Jawaid, M.; Saba, N.; Inamuddin. Effect of cellulose nano fibers and nano clays on the mechanical, morphological, thermal and dynamic mechanical performance of kenaf/epoxy composites. Carbohydr. Polym. 2020, 239, 116248. [CrossRef]

182. Chee, S.S.; Jawaid, M.; Alothman, O.Y.; Fouad, H. Effects of Nanoclay on Mechanical and Dynamic Mechanical Properties of Bamboo/Kenaf Reinforced Epoxy Hybrid Composites. Polymers 2021, 13, 395. [CrossRef] [PubMed]

183. Demosthenes, L.C.D.C.; Nascimento, L.F.C.; Monteiro, S.N.; Costa, U.O.; Filho, F.D.C.G.; da Luz, F.S.; Oliveira, M.S.; Ramos, F.J.H.T.V.; Pereira, A.C.; Braga, F.O. Thermal and structural characterization of buriti fibers and their relevance in fabric reinforced composites. J. Mater. Res. Technol. 2020, 9, 115-123. [CrossRef]

184. Samouh, Z.; Molnar, K.; Boussu, F.; Cherkaoui, O.; El Moznine, R. Mechanical and thermal characterization of sisal fiber reinforced polylactic acid composites. Polym. Adv. Technol. 2019, 30, 529-537. [CrossRef]

185. Zhang, Q.; Shi, L.; Nie, J.; Wang, H.; Yang, D. Study on poly(lactic acid)/natural fibers composites. J. Appl. Polym. Sci. 2012, 125, E526-E533. [CrossRef]

186. Yu, T.; Ren, J.; Li, S.; Yuan, H.; Li, Y. Effect of fiber surface-treatments on the properties of poly(lactic acid)/ramie composites. Compos. Part A Appl. Sci. Manuf. 2010, 41, 499-505. [CrossRef] 
187. Siakeng, R.; Jawaid, M.; Ariffin, H.; Sapuan, S.M. Mechanical, dynamic, and thermomechanical properties of coir/pineapple leaf fiber reinforced polylactic acid hybrid biocomposites. Polym. Compos. 2019, 40, 2000-2011. [CrossRef]

188. Manral, A.; Bajpai, P.K. Static and dynamic mechanical analysis of geometrically different kenaf/PLA green composite laminates. Polym. Compos. 2020, 41, 691-706. [CrossRef]

189. Han, L.; Ma, F.; Chen, S.; Pu, Y. Effect of short basalt fibers on durability, mechanical properties, and thermal properties of polylactic acid composites. Polym. Renew. Resour. 2019, 10, 45-59. [CrossRef] 